NBER WORKING PAPER SERIES

\title{
ACCESS TO SCHOOLING AND THE BLACK-WHITE INCARCERATION GAP IN THE EARLY 20TH CENTURY US SOUTH: EVIDENCE FROM ROSENWALD SCHOOLS
}

\author{
Katherine Eriksson \\ Working Paper 21727 \\ http://www.nber.org/papers/w21727 \\ NATIONAL BUREAU OF ECONOMIC RESEARCH \\ 1050 Massachusetts Avenue \\ Cambridge, MA 02138 \\ November 2015
}

Thank you to Ancestry.com and FamilySearch.org for access to data for this project. I appreciate additional data from Bhash Mazumder and Seth Sanders. I acknowledge financial support from the Center for Economic History at UCLA. This paper has benefitted most from advice from my dissertation committee: Leah Boustan, Dora Costa, Christian Dippel, and Walker Hanlon. I have also benefitted from conversations with participants of the NBER Development of the American Economy 2012 summer session, the Economic History Association 2012 and 2013 annual meetings, the Southern Economic Association 2014 meeting, SoCCAM, the 2014 CSWEP/CEMENT workshop, and seminar participants at multiple universities. I appreciate conceptual and data help from Roy Mill. I am grateful to my undergraduate research assistants, especially Ashvin Gandhi, and to Laura Hensey at the North Carolina State Archives, for help with data collection and analysis. The views expressed herein are those of the author and do not necessarily reflect the views of the National Bureau of Economic Research.

NBER working papers are circulated for discussion and comment purposes. They have not been peerreviewed or been subject to the review by the NBER Board of Directors that accompanies official NBER publications.

(C) 2015 by Katherine Eriksson. All rights reserved. Short sections of text, not to exceed two paragraphs, may be quoted without explicit permission provided that full credit, including $\mathbb{C}$ notice, is given to the source. 
Access to Schooling and the Black-White Incarceration Gap in the Early 20th Century US

South: Evidence from Rosenwald Schools

Katherine Eriksson

NBER Working Paper No. 21727

November 2015

JEL No. I20,N32

\begin{abstract}
A large gap in incarceration rates between black and white men has been evident since the early 20th century. This paper examines the effect of access to primary schooling on black incarceration in this period. I use the construction of 5,000 schools in the US South, funded by philanthropist Julius Rosenwald, as a quasi-natural experiment that increased the educational attainment of southern black students. I link individuals across Census waves in order to assign exposure to a Rosenwald school during childhood and to measure adult incarceration. I find that one year of access to a Rosenwald school decreased the probability of being a prisoner by 0.1 percentage points (seven percent of the mean). Using other data from archival and government sources, I find that Rosenwald schools affected juvenile crime and all categories of adult crime. I argue that most of the reduction in incarceration comes from increased opportunity costs of crime through higher educational attainment but also investigate school quality and migration responses. Effects are largest in counties which have less racist attitudes and which have a more literate population. These results contribute to a broader literature on racial gaps in social outcomes in the US throughout the 20th century.
\end{abstract}

\author{
Katherine Eriksson \\ Department of Economics \\ University of California, Davis \\ One Shields Avenue \\ Davis, CA 95616 \\ and NBER \\ kaeriksson@ucdavis.edu
}


In the contemporary United States, black men are disproportionately more likely than white men to be arrested and incarcerated. This racial gap in incarceration has been apparent in the data since the late nineteenth century. In 1910, blacks made up only thirteen percent of the population but twenty-seven percent of those in prison. ${ }^{2}$ In the South in 1910, blacks comprised 30 percent of the population yet made up 60 percent of those incarcerated (US Census Report 1910). ${ }^{3}$ The racial incarceration gap could have many causes, including discrimination in arrest and sentencing, differences in family background, lack of job opportunities for blacks, higher urbanization rates of blacks, and differences in educational attainment.

Little is known about the determinants of incarceration in the early part of the $20^{\text {th }}$ century. ${ }^{4}$ This paper collects a new dataset of the full universe of prisoners from the US Censuses between 1920 and 1940. I explore the role of one factor - disparities in education - in explaining the historical roots of the racial gap in incarceration. ${ }^{5}$ In particular, I analyze the relationship between access to primary education and the probability of incarceration as an adult between 1920 and 1940 among southern-born black men in the United States. I use the construction of almost 5,000 schools in 14 southern states for rural black students between 1913 and 1931, sponsored in part by northern philanthropist Julius Rosenwald, as a quasi-natural experiment which increased the supply of schooling for black children and therefore the educational attainment and literacy of blacks born in the South.

\footnotetext{
${ }^{2}$ In 2009, this disparity was even larger. Blacks made up 13.9 percent of the population and 39.4 percent of those incarcerated. This is likely due to the emergence of a series of factors which have led to higher black incarceration rates such as stricter penalties for drug offenses.

${ }^{3}$ In the North, blacks were 1.8 percent of the population but 9.6 percent of those incarcerated.

${ }^{4}$ One exception is Moehling and Piehl (2014) who look at immigrants in the first three decades of the $20^{\text {th }}$ century and find that immigrants assimilated towards natives between 1900 and 1930; that is, immigrants were unlikely to be incarcerated upon first arrival, but became more so after spending more time in the US. Another is Muller (2012) who finds that migration from the South to the North was partly responsible for increased black incarceration rates during the Great Migration; however, his paper uses aggregate data, not census micro-data.

${ }^{5}$ In this paper, I use incarceration in the census as my measure of crime, while thinking about factors which should affect actual criminality. Incarceration and criminality are by no means the same thing, particularly in the highly discriminatory environment of the Jim Crow South. I also look at some data about actual crimes committed later in the paper.
} 
I build a new dataset that matches the full universe of southern-born male prisoners from the 1920-1940 US Censuses, along with a comparison sample of non-prisoners, to their birth families in a previous census earlier in life. Based on their location in childhood, I assign to these men their likely exposure to a Rosenwald school, defined as the number of years between the ages of seven and thirteen that a Rosenwald school was present in his county. I also construct an alternative measure of exposure, which is the original measure weighted by the probability that any child could have obtained a seat in the school in each year. ${ }^{6}$

I find that access to education reduces incarceration later in life among adults. Exposure to a Rosenwald school for one year during childhood reduces the probability of being incarcerated for blacks by 0.1 percentage points or seven percent of the mean incarceration rate for blacks. This finding is robust to different comparison groups. I show that educational attainment is an important channel through which the probability of incarceration decreases, but also consider other mechanisms. Finally, looking at differential effects based on county characteristics, I find larger effects in counties with more educated black and white populations. I also find evidence that individuals were able to use higher education levels to avoid incarceration in places with better judicial systems and less racial antipathy.

My main specification employs county and birth cohort fixed effects and utilizes white men in the same birth cohort and county as a control group. Potential threats to identification can arise from characteristics of counties that changed over time (across birth cohorts) in a way that was correlated both with the construction of new schools and with subsequent criminality. I address

\footnotetext{
${ }^{6}$ That is, if a child had a school in his county for one year, but it could only serve half of the students, he would be assigned one half of a year by this measure.
} 
this concern in an alternate specification by comparing children in the same county who grew up closer to or farther away from a Rosenwald school. ${ }^{7}$

Finally, I collect data from non-census sources in North Carolina to examine potential mechanisms. I collect data on yearly admissions to the state prison, yearly court cases, and juvenile crime. I find that juvenile court cases decrease for black children in counties with exposure to Rosenwald schools; one year of access to a Rosenwald school reduces juvenile court cases by about 15 percent of the mean. The reduction in juvenile transgressions may have reduced criminal activity later in life. Admissions to the state prison and county level court cases also decrease; the first suggests that the effects of Rosenwald exposure did not work solely through the ability to avoid being arrested for vagrancy or other "nuisance" crimes (Naidu 2010).

This paper contributes to two literatures. The first concerns the convergence in wages and other outcomes between blacks and whites over the $20^{\text {th }}$ century. In 1910, blacks lagged behind whites in completed schooling by three years on average, a legacy of slavery and of poor investments in southern black schools (Margo 1990, Aaronson and Mazumder 2011). The racial gap in schooling diminished substantially by 1940, contributing to the decline in the black-white wage gap over the 1940's (Heckman et al 2000, Smith and Welch 1989). My estimates suggest that the black-white incarceration gap should have been cut in half over the $20^{\text {th }}$ century due to these relative increases in black educational attainment. The fact that black incarceration rates have not only remained persistently high but also have increased further since the mid-1970s, suggests that other factors have counteracted the forces of educational convergence.

This paper also speaks to work on the social returns to education. One of the social returns to education is a significant reduction in criminality. ${ }^{8}$ In 2007, the Department of Justice

\footnotetext{
${ }^{7}$ A second concern might be that parental background differs among those who have exposure to schools and those who do not; for example, more literate parents could be migrating into certain counties as Rosenwald schools are being built. I provide evidence that this is likely not true.
} 
estimated that victims of crimes face $\$ 15$ billion in losses and that the prevention and punishment of crimes cost $\$ 179$ billion for local, state and federal governments. Committing crimes also has long-run costs for the criminal; individuals with a criminal record often find it difficult to get a job, and those jobs they do get pay lower wages (Western, Kling, and Weiman 2001).

The relationship between education and crime has been extensively studied in a modern context. The closest paper to mine is Lochner and Moretti (2004) who find, in a contemporary context, that the probability of incarceration for blacks and whites decreases following an additional year of school. ${ }^{9}$ All papers in this area focus primarily on secondary schooling, using variation induced by compulsory schooling laws, whereas I focus on elementary school. If there are decreasing returns to education, we might expect results to be stronger at these younger ages. My results imply that one year of school reduces the probability of being incarcerated by 0.41 percentage points which is similar to Lochner and Moretti who find a social return to school for blacks of 0.4 percentage points. Note, however, that relative to the period-specific means, my estimates are almost three times as large. ${ }^{10}$ Additionally, papers looking at other social returns to school have found that the institutional context matters; I focus on a poorer, highly unequal society and so my results are potentially more applicable to developing countries today. Finally, this intervention was large and affected approximately $1 / 3$ of black children; effects of such a

\footnotetext{
${ }^{8}$ Other research has also shown that education contributes to improvements in health, more targeted fertility, and increases in voting and civic behavior (Lleras-Muney 2005, Clark and Royer 2009, Aaronson et al 2014, Milligan et al 2004).

${ }^{9}$ Lochner and Moretti (2004) is the best known study; their results have been replicated and expanded in Sweden, the UK, and other European counties (Hjarlmarsson et. al 2010, Machin et. al 2011, Meghir et al. 2011). Other work has looked at the relationship between school quality and crime (Deming 2011) and finds a significant effect. Anderson (2014) shows that juvenile crime decreases with higher minimum dropout ages for students.

${ }^{10}$ The mean black incarceration rate in contemporary data is 3.6 percent whereas in my historical context it is only 1.4 percent.
} 
large program might differ from estimates using compulsory schooling laws which only affect education levels at the individual level.

The structure of this paper is as follows. Section II provides historical background about black/white differences in incarceration and in schooling through the $20^{\text {th }}$ century. In section III, I describe the data and exposure to Rosenwald schools. Section IV discusses my estimation strategy and potential threats to identification. Section V presents results from my primary sample and additional data. Section VI examines robustness and alternative specifications. I conclude in Section VII.

\section{Historical Background}

\section{A. Incarceration rates by race and region over time}

The gap between white and black incarceration rates was evident as early as 1890. In 1890, blacks were 3.2 times more likely to be incarcerated than whites (Petersilia and Reitz 2012). ${ }^{11}$ Contemporary observers attributed this difference in incarceration rates to a variety of factors including poverty, discrimination, lack of education, and "moral degradation” (Sellin 1900). Figure 1 shows the evolution of black and white state and federal prison admission rates from 1926 to 1986 (Department of Justice, 1986). Panel A reveals that prison admission rates were higher for blacks than for whites in all years, with approximately eight per 10,000 blacks admitted nationally through the early 1960s compared to four whites. The racial gap is present in both the North and the South, despite higher admission rates in the North in the 1920s and 1930s. These graphs demonstrate that the current black-white incarceration gap is not a recent phenomenon but, rather, has been present throughout the $20^{\text {th }}$ century. Any explanation of differences in incarceration rates needs to take into account the historical patterns of

${ }^{11}$ In 2010, this number was 6.4. It grew from 3.2 in 1890 to 4.3 in 1923, and was as high as 7.1 in 2000. 
incarceration. Most literature has focused on the evolution of this gap since the 1970's. This paper is one of the first to examine incarceration in the first half of the $20^{\text {th }}$ century.

The debate about whether, and to what extent, education reduces crime and therefore incarceration goes back to the early $20^{\text {th }}$ century and was in fact a central topic of concern at that time. John Roach Stratton (1900) argued that the "race problem," i.e. the high crime rates and "immorality" of blacks, could not be solved by education. Stratton thought that the positive correlation between increasing black incarceration and increasing levels of black education between the end of the Civil War and 1900 showed that education actually increased criminality. He argued that allowing blacks to gain education and move from farms to cities to find work increased crime rates at very little benefit to blacks or whites. In fact, Governor Vardaman of Mississippi used this reasoning when restricting funds for black schools in 1904 (Hollandworth 2008). On the other side of the argument, Booker T. Washington and W. E. B. Du Bois sought to explain higher black criminal behavior as a result of low wages and discrimination. The issue of high black incarceration rates was one motivation for Booker T. Washington's interest in improving black schools, out of which grew the Rosenwald Initiative.

\section{B. Black schooling and Rosenwald schools}

Blacks in the birth cohorts between 1880 and 1910 completed on average three fewer years of education than whites. Motivated by his concerns about the low levels of funding for black education, Booker T. Washington, principal of the Tuskegee Institute in Alabama, reached out to Northern philanthropist and businessman Julius Rosenwald. ${ }^{12}$ Rosenwald agreed to fund a pilot program supporting the construction of six black schools in 1913-14, with the promise of up to

\footnotetext{
${ }^{12}$ The Rosenwald School Initiative was not the only black schooling initiative in this time. The Jeanes Fund provided teacher training. Kreisman (2014) shows that this fund also increased school enrollment and literacy of black youth. Other philanthropic interventions are described in Donohue, Heckman and Todd (2002).
} 
100 more. The original schools were built primarily in Alabama; by 1920, the program supported 716 schools in eleven southern states. By 1931, the Fund had supported the building of 4,983 schools explicitly targeting rural students.

Rosenwald believed that, in order to be successful, communities needed to "buy-in" to, or make investments in, any educational endeavors. This view, coupled with Washington's belief in black self-reliance, led to the use of a matching grant approach, whereby local communities had to raise anywhere from 75 up to 90 percent of the funds for a new school. The early schools received about 25 percent of the cost in grant money, whereas this number fell to $10-15$ percent by the later years of the program. On average, local school districts contributed about half of the funds for the school with about 20 percent coming from black citizens and 4 percent from white citizens. After the schools were built, they were reliant on the local community and the state for funding. The program ended in 1931 with Rosenwald's death and the decreased value of Fund assets after the collapse of the stock market. In addition to helping to build schools, the Fund also provided some money for teacher training schools, teacher homes, and shops.

By the end of the program, 76 percent of counties in 14 southern states had a school and 92 percent of black students in these states lived in a county with a school. ${ }^{13}$ The location of the schools was not randomly assigned. Following Aaronson and Mazumder (2011), I test whether a variety of county-level variables predict school locations. I find that counties with higher literacy rates of blacks and whites or with a higher percentage of black farmers tend to have schools and to receive them earlier than other counties. There is some evidence of a positive correlation between the percentage foreign born and receiving a school. Counties with more lynchings and more per capita expenditure are jails are slightly less likely to build schools. See Appendix A for details.

\footnotetext{
${ }^{13}$ I omit Missouri from my analysis because only 11 schools were built there.
} 
In an earlier evaluation of the direct effects of the program, Aaronson and Mazumder (2011) find that the schools could serve 36 percent of rural black students. They show that the Rosenwald schools were a significant contributor to the narrowing of the black-white schooling gap by 1940. In particular, Aaronson and Mazumder estimate that Rosenwald schools increased school attendance by about 5 percentage points. Full exposure (seven years) to a Rosenwald school also increased educational attainment by 1.2 years; put otherwise, one year of Rosenwald exposure increased years of education by 0.17 years.

\section{Data}

\section{A. Measuring incarceration and constructing the primary sample}

I am interested in estimating the effect of access to a Rosenwald school on adult outcomes, particularly on the likelihood of committing a crime or being imprisoned. Lacking historical data on crime or arrest rates, I instead rely on individual-level data on incarceration as of the census date. ${ }^{14}$ I calculate this measure from US census data for the years 1920-1940. To do so, I assemble a dataset that includes the full universe of prisoners and a sample of non-prisoners in each relevant census.

I identify prisoners in each census via a three-step process. First, I take men reporting a relationship to household head of "Prisoner" in the full census indexes from FamilySearch.org. Second, many prisoners did not report this relationship to household head but instead reported "Inmate" or, often, the field was left blank; therefore, I identify any census images which contain a substantial number of inmates or blank relationship fields. Third, I look-up by hand each of

\footnotetext{
${ }^{14}$ The FBI Uniform Crime Statistics do not become available for a substantial number of counties until the 1960's. Crime statistics are only available from census reports or for major cities prior to the start of the FBI UCR. This is the first paper to collect individual data on incarceration by race and for the full country. Moehling and Piehl (2014) collect individual data for immigrants and non-immigrants living in select northern states in the 1900-1930 censuses.
} 
these images to determine whether the men are incarcerated (as opposed to living as inmates in a hospital or other facility). Full details about the main prisoner sample are found in Appendix B.1. Non-prisoners are drawn from the full indexes of each census. I construct a 20 percent sample of men in each relevant census for my main analysis. ${ }^{15}$ I restrict the sample to men between ages 18 and 35 who were born in one of the 14 Rosenwald states in my sample.

I identify the town or county in which sample individuals grew up by matching all men to the relevant census one or two decades earlier to find the individual living in their birth family. Men less than or equal to 23 years old are matched to the previous census while those between 24 and 35 years old are matched over a twenty year period. ${ }^{16}$ To match individuals, I follow the procedure pioneered by Ferrie (1996) and used in Abramitzky, Boustan, and Eriksson (2012). I first standardize first and last names using the NYSIIS algorithm (Atack and Bateman 1992) which spells names with the same phonetic sound identically. Individuals are then matched by first name, last name, state of birth, race, and age across census waves. I allow individuals to misreport their age by up to two years in either direction. Inherent in any matching procedure is a trade-off between sample size and accuracy. To prioritize accuracy in order to minimize measurement error in my measure of Rosenwald exposure, I go one step further and require individuals to be unique by name/birthplace/race within a 5 year age band. ${ }^{17}$ If I do not require

\footnotetext{
${ }^{15}$ There is no reason except computing time to restrict to a 20 percent sample instead of the full population. The full sample yields very similar results but is computationally time-consuming. A previous version of this paper used Ipums 1\% samples from 1920, 1930, and 1940.

${ }^{16}$ Results are robust to using different cutoffs. I have moved the cutoff as far as age 26. This cutoff was determined by calculating the age at which approximately 90 percent of individuals appear to be living at home in the 1910 census. The percentage living at home at young ages increases with later censuses. In 1910, 88.6 percent of black children and 92.4 percent of white children who are 16 years of age or younger report a relationship to household head of "child", "grand-child", "sibling", or "other relative".

${ }^{17}$ That is, I require an individual's name/birthplace/race combination to be unique within their age plus or minus two years. I impose this restriction in both childhood and adult years.
} 
this more stringent form of uniqueness, I find smaller effects of Rosenwald exposure. ${ }^{18}$ Accuracy may, however, come at the cost of representativeness if the uniqueness of an individual's name is correlated with his socio-economic status. The match rates in my study are consistent with the literature, averaging around 30 percent. Matching details and sample sizes are available in Appendix B.2.

Summary statistics are shown in Table 1. Black individuals are four times more likely than whites to be incarcerated in my sample (1.4 percent versus 0.34 percent). Incarceration rates for both races are increasing over time. Average years of exposure to Rosenwald schools are slightly higher for prisoners than non-prisoners. The average level of exposure with the "Likely Seats" measure is 0.4 years. With the "School in County", it is 1.4 years overall. More prisoners are found outside of the South than non-prisoners and this is true for both races. The probability of being found outside of the South as an adult increases from 1920 to 1930 and from 1930 to 1940. By 1940, 22 percent of black prisoners and 14.1 percent of black non-prisoners are outside of the South, a discrepancy which is due to higher incarceration rates outside of the South. For the 1940 census only, I can examine education levels; I find, as expected, that prisoners are less educated than non-prisoners. Black prisoners have on average 5.54 years of schooling compared to 5.8 for black non-prisoners. The gap is larger for whites: prisoners have 7.4 years of school compared to 8.9 years for non-prisoners.

\footnotetext{
${ }^{18}$ One main concern in this paper stems from assigning individuals an incorrect county of birth and therefore incorrect exposure to Rosenwald schools. If this is random, I expect attenuation bias in the coefficient of interest. In fact, coefficients decrease by about 1/3 when I relax the 5-year-band requirement, suggesting that the more stringent uniqueness requirement reduces measurement error substantially. Results are not shown here but are similar in sign.
} 


\section{B. The location of Rosenwald schools}

Information about the Rosenwald school program is taken from Aaronson and Mazumder (2011). The dataset of 4,983 schools was compiled from school-level index cards archived at Fisk University. Information available includes school name, county location, year of construction, and some information about funding sources and the size of the school. The earliest Rosenwald schools were located in Alabama in 1913; by 1932, schools had been built in 15 Southern states. ${ }^{19}$

The school-level cards do not, for the most part, contain information on the school's address within a county. For the North Carolina sub-sample of 786 schools, I used historical society documents and school directories (North Carolina Department of Education 1937, 1942) to determine the town in which the school was located. I was able to locate 757 schools. This procedure is limited to North Carolina because it is the only southern state with readily available school directories. Not every town got a school in North Carolina—out of 1850 towns identified in my data, only 757 received a school. On average, there were about 8 schools per county by 1931 and the timing of when these schools were built varied greatly across counties. One might worry that North Carolina is not representative of the South. ${ }^{20}$ North Carolina was in fact one of the poorest states in 1910, with the lowest per capita income and low literacy rates. Incarceration rates in my sample are also slightly higher than in other states; for blacks, the mean incarceration rate was 2.05 percent relative to 1.4 percent in the full sample. I expect that results might be stronger in this state than in other states.

\footnotetext{
${ }^{19}$ Only a few schools were built in Missouri so I omit Missouri from the analysis. My analysis therefore includes 14 states.

${ }^{20}$ In 1910, North Carolina's per capita income was only \$123, similar to South Carolina’s $\$ 126$ but lower than all other Southern states (Klein 2009). However, North Carolina's black pupil expenditures tracked those of other states between 1910 and 1950 while expenditures on white students were significantly lower than other states (Margo 1990). Furthermore, North Carolina had one of the lowest literacy rates in the region, with 81.6 percent of white men and 49.6 percent of black men between 20 and 64 being literate in 1900 (IPUMS 2010).
} 


\section{Calculating exposure to Rosenwald schools}

Exposure to a Rosenwald school varies across towns and counties in the South as well as by birth cohort. Children who were born before 1906 would have been too old to attend even the first Rosenwald school. As the program expanded, later birth cohorts enjoyed a higher likelihood of attending a Rosenwald school. However, the Rosenwald program did not build schools uniformly throughout the South; out of 1,168 counties in the states with Rosenwald schools, 76 percent received at least one school. Aaronson and Mazumder (2011) find little correlation between pre-existing black socioeconomic characteristics and the placement of Rosenwald schools in a county but do find a relationship between white literacy and school construction. Carruthers and Wanamaker (2013) argue that schools were more likely to be built in larger counties with higher urbanization, per-pupil spending and enrollment of black youth. I discuss these and other potential threats to identification in Section IV and, more thoroughly, in Appendix A. I also show results with county-year fixed effects in my robustness section to show that results are robust to accounting for factors changing within a county over time which affected all cohorts and races.

For the full southern-born sample, I assign to individuals a measure of their likely exposure to a Rosenwald school based on their age and their county of residence during childhood. Following Aaronson and Mazumder, I calculate two measures of exposure. The first is a simple count of the years between ages 7 and 13 in which a child had a Rosenwald school in his county; this varies between zero and seven. This measure is referred to as "School in County" in results tables. The second measure, which takes into account that Rosenwald schools were not large enough for all students, is the proportion of black students in the county who could be served by a Rosenwald school added over the years during which the child was between 7 and 13. This 
measure is smaller than the first, but is a better measure of how likely a student was to attend a Rosenwald school. ${ }^{21}$ Therefore, this measure is used in most analysis and is referred to as "Likely Seats". The counts of potential students in a county are taken from Aaronson and Mazumder (2012) who used the census indexes on Ancestry.com to count all children within a county in each census year and then extrapolated between years.

I take advantage of the specific school locations in the North Carolina sample to create a third measure of exposure. One concern with the full southern sample is that the placement of Rosenwald schools may not be truly exogenous. Even if the timing of school construction is not correlated with time and race-varying county-level characteristics, it could have been affected by unobservable factors such as the degree of racial antipathy. This new measure is calculated as the number of years a student had a school within a five mile radius of their town between the same ages as above. In this within county analysis, I compare individuals who were the same age and lived in the same county but who grew up different distances from a school. This estimation strategy makes use of variation in the length of exposure to Rosenwald schools and in the exact placement of these schools within counties. I call this measure "Local Radius". Results with this measure will be robust to anything changing in a county over time, affecting different cohorts differentially, and which affects blacks and whites. However, I note that the specific location within the county is possibly endogenous with respect to the characteristics of the specific towns themselves. $^{22}$

\footnotetext{
${ }^{21}$ For example, if a school could fit half of the students in a county, then each individual living in that county would get $1 / 2$ a year of exposure.

${ }^{22}$ The challenges with this measure are equivalent to the challenges when using twin or brothers studies—-why does one twin get more education than the other? In this case, why did one town receive a school and the other did not?
} 


\section{Estimation Strategy}

\section{A. Reduced form estimation of the effect of Rosenwald schools on incarceration}

I estimate the effect of being exposed to a Rosenwald school for one additional year on the probability of being incarcerated later in life. My estimation strategy exploits differences across counties in the number of Rosenwald schools as well as variation across cohorts within a county in exposure to a Rosenwald school at relevant ages. In most of my analysis, I also contrast black and white students in the same county and cohort. All regressions also include dummy variables for each age by race to allow for different white and black age-incarceration profiles. ${ }^{23}$

My first estimating equation (1) is restricted to the black sample only. I use a linear probability model and estimate ${ }^{24}$ :

$$
\text { prisoner }_{\text {iasct }}=\alpha_{c}+\gamma_{t}+\theta_{a}+\pi_{s t}+\beta_{1} \text { exposure } e_{i c t}+\varepsilon_{i c t}
$$

where Prisoner equals 1 if individual $i$ (of age $a$ who lived in county $c$ and state $s$ in childhood at census date $t$ ) is incarcerated at the time of the adult census. I scale the outcome variable by 100 so that coefficients can be interpreted as percentage point changes. I include state fixed effects interacted with childhood census year, childhood census year fixed effects, age and black times age fixed effects, and childhood county fixed effects. The coefficient of interest is $\beta_{1}$ which measures the change in incarceration for an extra year of exposure to a Rosenwald school, and is identified by comparing cohorts in the same county who were exposed to the new school with those who were too old to benefit.

\footnotetext{
${ }^{23}$ I create sample weights that are inversely proportional to the match rate within a census year-race-prisoner status cell. I do this for two reasons: first, because I have a full 100 percent sample of prisoners but only a 20 percent sample from of non-prisoners, I must weight non-prisoners by a factor of five to achieve the correct incarceration rates; second, match rates differ by race, census-year and prisoner status so I weight by the inverse of the match rate so that I measure the effects of Rosenwald schools relative to the correct incarceration rates.

${ }^{24}$ Results from a probit regression are quantitatively similar. However, probit regression is inconsistent (Greene 2004) in a regression with fixed effects so I prefer the linear probability model.
} 
One concern with this specification is that there might be factors which are changing over time within counties and which affect cohorts differentially. I address this in two ways. First, I show later in a robustness table that results are similar if I include state-specific or countyspecific cohort trends. Second, I use whites as a comparison group. This allows me to account for any local factors that are changing within a county over time that have similar effects on whites and blacks.

My main estimating equation therefore is (2):

$$
\begin{aligned}
\text { prisoner }_{\text {iarsct }} & =\alpha_{c}+\gamma_{t r}+\theta_{\text {ar }}+\pi_{s t}+\beta_{1} \text { black }_{i}+\beta_{2} \text { exposure }_{i c t}+\beta_{3} \text { black }_{i} * \text { exposure }_{i c t} \\
& +\varepsilon_{i c t}
\end{aligned}
$$

for individual of race $r$ and the characteristics from Equation (1). I add race-specific childhood census year fixed effects, age fixed effects interacted with race, and birth state times childhood census year fixed effects. ${ }^{25}$ The coefficient of interest in this equation is $\beta_{3}$ which measures the additional effect of a year of exposure to a local Rosenwald school on black youth above any effect that there may be of Rosenwald schools on white youth. To the extent that Rosenwald resources may have been diverted to white schools, $\beta_{2}$ picks up any effect on white individuals.

It is possible that Rosenwald funds freed up money in the local budget which could then be siphoned off to white schools. Carruthers and Wanamaker (2013) find significant crowd-out of the Rosenwald initiative. An additional dollar of Rosenwald spending was associated with another $\$ 2.12$ of public spending for black and white schools, but 63 percent of this gain accrued to white schools. ${ }^{26}$ For this reason, I control for the effect of Rosenwald exposure on whites $\left(\beta_{2}\right)$ and interpret $\beta_{3}$ as the differential effect of Rosenwald schools on incarceration for blacks.

\footnotetext{
${ }^{25}$ Results are robust to including county-year census covariates such as literacy, home ownership, and percent farming (not shown). This is equivalent to including county-year fixed effects which I do in Table 12.

${ }^{26}$ In light of these findings, they argue that Aaronson and Mazumder's results are consistent with higher marginal returns to school spending on black schools.
} 
My estimate of $\beta_{3}$ can still be biased if there are local events that are correlated with the timing of construction of Rosenwald schools, are correlated with trends in incarceration, and which affect the older (unaffected) and younger cohorts differentially; additionally, by comparing white and black children, these factors must affect the two races differently. However, it is hard to conceive of omitted variables that meet all of these criteria. For example, we might think that some counties have more racist attitudes which would lead them not to build schools and to also tend to incarcerate black men more often, but these attitudes would have to be changing over time so as to affect the two cohorts differently. Finally, note that Rosenwald school exposure is measured in childhood but incarceration is measured at least ten years later so any county-level confounding factor in terms of attitudes during childhood and then attitudes during adulthood towards incarceration would have to be constant throughout this gap. ${ }^{27}$

We might also be worried that the timing of school building within counties is correlated with unobserved factors. This problem would not be eliminated with county fixed effects. Particularly in North Carolina, almost all counties ended up with at least one school by the end of the program, so it might not be across-county differences that are a problem, but that certain counties decided to build schools earlier or later. In Appendix A, I show that that black literacy, increases in the share foreign born, and increases in population density predict the length of time from the beginning of the program in 1913 to the date a county first built a school. To handle the idea that variables which are changing over time could explain my results, I control for census year-county fixed effects in my robustness table and results are not affected. I also show in the robustness table that results are robust to including state*cohort and county*cohort trends. Finally, I also use an alternative exposure measure, "Local Radius”, in North Carolina which

\footnotetext{
${ }^{27}$ Note that household characteristics are constant from the perspective of the individual so if parental education is correlated with opening of the schools, then there could still be a problem.
} 
compares individuals of the same race and same cohort but who live on opposite sides of the same county.

\section{B. Estimating the effect of Rosenwald schools on other outcomes}

Thus far, my main interest has been the direct effect of Rosenwald schools on incarceration. One likely channel through which Rosenwald schools reduced incarceration is by increasing the educational attainment of its black pupils. They could also have encouraged migration to the higher wage North. As a result, I consider education, income, and migration as possible channels through which Rosenwald schools reduced incarceration. These results complement Aaronson and Mazumder (2011), who show that Rosenwald schools increased school enrollment of affected cohorts and improved educational attainment of WWII enlistees.

My equation follows the format of equation (2) above. I estimate:

$$
\begin{aligned}
\text { outcome }_{\text {iarsct }} & =\alpha_{c}+\gamma_{t r}+\theta_{\text {ar }}+\pi_{\text {sr }}+\beta_{1} \text { black }_{i}+\beta_{2} \text { exposure }_{i c t}+\beta_{3} \text { black }_{i} * \text { exposure }_{i c t} \\
& +\varepsilon_{i c t}
\end{aligned}
$$

where $\beta_{3}$ is the effect of exposure to a Rosenwald school for an extra year for blacks versus whites. Education is measured in 1940 as years of completed education.

I use the first stage estimate to calculate a Wald estimate of the effect of literacy on incarceration. That is, what is the predicted change in incarceration rates for someone who obtains an extra year of school? This is calculated by dividing the reduced form estimate of the effect of Rosenwald schools on incarceration by the first stage estimate of the effect of Rosenwald schools on years of education. In order for this to be interpreted as an instrumental variable estimate, I must be willing to assume that Rosenwald schools only affected incarceration 
through years of education. In fact, access to schooling may have reduced incarceration in other ways, namely by keeping children occupied during the day or increasing school quality.

This school building program was taking place during a period of high levels of migration to the North. I consider migration as a potential mechanism for reductions in incarceration in my later analysis, but I also note here that high rates of black out-migration was a potential motivation for counties to make use of Rosenwald funds despite the overwhelming representation on whites on local school boards. Margo (1990) argues that investments in education were one way that southern governments could discourage migration to the North. In fact, I show in the next section that exposure to a Rosenwald school seems to be associated with a slightly lower probability of migrating.

\section{Results}

\section{A. Reduced form effects of Rosenwald exposure on incarceration later in life}

My empirical analysis begins by estimating the relationship between exposure to a Rosenwald school and incarceration later in life (see equations 1 and 2). In columns (1) and (3), I define my first measure of exposure as "Likely Seats," referring to the number of years a school was in a county between ages 7 and 13, weighted by the probability of having a seat. In columns (2) and (4), exposure is "School in County" which is measured as the number of years a student had a school anywhere in his county between the ages of 7 and 13.

I start in columns (1) and (2) by considering the black sample only. Given that incarceration rates were so dissimilar for whites and blacks in this time period, and that whites and blacks were treated differently by justice systems in the Jim Crow era, whites may not be a good comparison group for blacks. I find that an extra year of exposure reduces black 
incarceration by around 0.07 percentage points using the "Likely Seats" measure or 0.03 percentage points using the "School in County" measure. The effect using my preferred "Likely Seats” measure implies that one year of exposure reduces incarceration by about five percent of the average black incarceration rate. The fact that the "Likely Seats" measure produces larger points estimates is what we would expect if we think about these two measures as "intent to treat” measures. The first measure is twice as likely to lead to an extra year of schooling (Aaronson and Mazumder 2011). It is also a better measure of the likelihood that a student attends a Rosenwald school.

I then turn to specifications that use whites as a control group in the next two columns. Using the first measure of exposure, one year of exposure to a Rosenwald school reduces the probability of being a prisoner by 0.1 percentage points, or just under seven percent of the average propensity of a black individual to be imprisoned. This number falls to 0.06 percentage points when using the second measure of exposure. The rest of the analysis in this paper uses whites as a control group. In fact, the white coefficient is never economically or statistically significant.

Table 3 restricts the analysis to the North Carolina subsample. As noted above, North Carolina is poorer than most southern states at this time and had higher exposure to Rosenwald schools. Results are larger than in the whole sample, at -0.21 and -0.14 percentage points for the "Likely Seats" and "School in County" measures, respectively. However, these larger numbers are relative to a much larger base incarceration rate of 2.05 percent for blacks, representing ten and seven percent decreases in the incarceration rates, respectively. Exposure is also substantially higher in North Carolina where more schools were built than any other state. In Column (3), I add local-level variation using the "Local Radius" measure. Recall that "Local 
Radius” measures a child as exposed if they lived within a five mile radius of a Rosenwald school during the relevant year of childhood; it is then added between ages 7 and 13 . By this measure, one year of exposure to a school reduces the probability of being a criminal by 0.11 percentage points. This is equivalent to reducing the probability of being incarcerated by about 5 percent of the base incarceration rate of blacks. In all regressions, exposure of whites to Rosenwald schools is small and insignificant, indicating that Rosenwald schools did not affect white incarceration.

\section{B. Effects of Rosenwald exposure on education, income, and migration}

The above results suggest that Rosenwald schools reduced the criminality of black students later in life. I look at three main mechanisms in this section: education, income, and migration. The most likely mechanism for this decrease in incarceration is that educational attainment raises the opportunity cost of engaging in criminal activity by increasing education levels and therefore wages. Alternatively, more time in school could act through the “incapacitation effect” whereby staying in school keeps children occupied, preventing them from entering a life of crime; I cannot disentangle these effects here, but I show later that Rosenwald schools did affect juvenile transgressions which suggests some role for incapacitation. Another major mechanism through which education could affect incarceration is through migration; there is evidence that migration from the South to the North was somewhat positively selected, one dimension of which could be education (Collins and Wanamaker 2013). Furthermore, incarceration rates were higher in the North than South, so moving to a northern city might increase the propensity to be incarcerated. If Rosenwald schools increased the probability of 
migrating, I would be understating the effect of Rosenwald schools on incarceration in the absence of migration.

Because the 1940 census is the only census with education levels, I restrict to this census. I start by replicating my main result in this census. Column (1) of Table 4 shows that an extra year of Rosenwald exposure reduces incarceration by 0.05 percentage points in this census. This is lower than the main effect from Table 2, likely because exposure rates are higher in this census. I also lose some of the variation from unexposed cohorts that I had in the 1920 and 1930 censuses and so the estimate is less precisely estimated.

I then turn to education levels. Column (2) of Table 4 shows that an extra year of Rosenwald exposure increases education levels by 0.11 years. This is somewhat smaller than the effect found by Aaronson and Mazumder who use WWII draft cards and find that exposure to a Rosenwald school increases educational attainment by 0.17 years. ${ }^{28} \mathrm{I}$ also examine the effect on the probability of achieving some high school and the probability of finishing high school. I find in column (3) that the probability of completing some high school increases by 1.3 percentage points for an extra year of Rosenwald exposure, while the probability of completing high school increases by 0.63 percentage points. These numbers are both large relative to the sample means for blacks of 23 and 10 percent, respectively, and are consistently about $60 \%$ of the size of the coefficients found by Aaronson and Mazumder.

I calculate a Wald estimate of the social return to education based on the results above. The Wald estimate is the reduced form coefficient divided by the first stage. By this estimate, one more year of school would reduce the likelihood of later-in-life incarceration by about 0.41 percentage points. In comparison, Lochner and Moretti find that an additional year of schooling

\footnotetext{
${ }^{28}$ Aaronson and Mazumder consider the effect of full exposure for all seven years and find effects between 1.2 and 1.5 years of school. I divide these numbers by seven to compare my results.
} 
reduces the likelihood of imprisonment by 0.4 percentage points. If, however, I use the estimate of 0.17 years of education for one year of exposure to a school from Aaronson and Mazumder (2011), I find that an additional year of schooling reduces imprisonment by 0.2 percentage points. $^{29}$

These estimates would be valid two-sample instrumental variables estimates if the only mechanism through which Rosenwald schools affected incarceration was through education (Angrist and Krueger 1992; Solon and Inoue 2010). However, it is likely that the Rosenwald program affected criminality through multiple channels. Wald estimates are presented here simply to give an idea of the magnitude of the coefficients that are estimated in the reduced form analysis.

Next, I consider income. In 1940, the census only asked about wage income, so I am missing income observations for almost half of my sample. However, in column (3) I find that income increases 1.63 percent for an extra year of exposure. ${ }^{30}$ It is likely that Rosenwald schools increased educational attainment through attendance but also increased school quality. For a return to education of 6 percent $^{31}$, we would predict that income would only increase 0.66 percent due to the educational attainment increases. This means that over half of the effect on income comes through increased school quality. ${ }^{32}$ Taking Aaronson and Mazumder’s 0.17 years of schooling, this would mean that increases in education would increase income by 1.05 percent, leaving 35 percent of the effect to school quality.

\footnotetext{
${ }^{29}$ These Wald estimates come from dividing the first stage coefficient ( 0.05$)$ by the 0.11 or 0.17 years of schooling first stage coefficient.

${ }^{30}$ This is most likely an underestimate since I am missing income data for those who are self-employed. Over half of the self-employed in the sample are farmers or farm laborers who remain in the South.

${ }^{31}$ Authors calculations for blacks in the 1940 Ipums 1\% Census sample.

${ }^{32}$ Alternatively, it could be that exposure to Rosenwald schools increases the propensity to migrate to the North where wages are higher. I find no evidence of this.
} 
Finally, I consider the propensity to be living outside of the South in 1940. Surprisingly, an extra year of Rosenwald exposure slightly reduces the probability of moving to the North by 1940, lowering the probability by 0.4 percentage points. This suggests that despite the fact that these schools increased education levels, they did not have a large positive effect on migration. If anything, my main effects slightly overestimate what the effect of Rosenwald schools on incarceration would be in the absence of migration responses. ${ }^{33}$ This finding is consistent with the argument made in Margo (1990) that Southern investments in education were in response to out-migration of black workers.

\section{Heterogeneous effects by county characteristics}

This section considers heterogeneous effects of Rosenwald schools on incarceration by different county characteristics. Data sources are described in Appendix B.3. I first test whether the effect of the program was larger in disadvantaged counties. I split results based on characteristics of the childhood county of residence. I expect to see larger effects of access to education in counties with lower initial levels of black schooling and in counties which had a higher share of the population which were slaves in 1860. I then look at a group of variables that I take to measure racial attitudes in the county. In the South at this time, lynching was often an extrajudicial means of punishing crime, so counties with fewer lynchings most likely had less racist attitudes. I also consider whether counties which spent more or less money on courts and jails have different effects. Relatedly, I expect the effect of access to education to be muted in counties with more negative racial attitudes, in which blacks are likely to be imprisoned unfairly (and almost at random) for small infractions, rather than as the result of committing a crime; to

\footnotetext{
${ }^{33}$ This is in contrast to the findings of Aaronson and Mazumder (2011) who find increases in migration between 1935 and 1940, but only for the 17-21 year old age group. I argue that assigning Rosenwald exposure based on location in 1935 is likely assigning exposure after many individuals have already migrated, at least within the South.
} 
test this I look at counties in which Strom Thurmond received more than 40 percent of the 1948 presidential election vote versus places where he received less than 40 percent.

Tables 5 and 6 present specifications that allow the effect of access to a Rosenwald school to vary by county characteristics. Table 5 looks at whether the effect of Rosenwald schools differs by county pre-Rosenwald socio-economic characteristics, as well as by the intensity of farming on large plantations. Columns (1) and (2) start with black literacy. Access to a Rosenwald school had a larger effect in counties with high black literacy, meaning that more literate counties were more able to take advantage of the opportunities provided in Rosenwald schools. I find a similar pattern for white schooling in columns (3) and (4): individuals from counties with higher levels of white school attendance have a larger effect of a year of exposure than those from counties with low white schooling.

I find no evidence that the black population share in a county matters for the effect of Rosenwald schools even though incarceration rates are nearly twice as high in counties with a low black share of the population. Finally, in Columns (7)-(10), I find no evidence that the share of farming on cotton plantations or the share of the population that were slaves in 1860 produce different effects by county type.

Table 6 turns to measures of a county’s criminal justice system and racial attitudes. I look at counties that did and did not experience a lynching in the past 40 years, and those with high and low per capita expenditures on jails and courts. Effects are lower in counties that had a recent lynching but are higher in counties with a recent court-ordered execution. I take this to mean that the effects of Rosenwald schools on incarceration were larger in areas where the rule of law was stronger. If lynching is a substitute for the rule of law, or put otherwise, more common where the rule of law is weak, then we would expect that incarceration rates are lower 
in counties that had a recent lynching, which is indeed the case. The next part of the table turns to per capita expenditures from the 1902 Census of Government. We see a pattern consistent with the story above; counties which had higher per capita expenditures on courts and jails twenty years before the schools were built see larger effects of Rosenwald schools. Finally, the table considers a measure of racial antipathy: the share of the vote for Strom Thurmond in 1948. I find that in counties with a high vote for Strom Thurmond there are smaller effects than in counties with a low vote for his candidacy. This suggests that Rosenwald schools were more effective in counties with positive racial attitudes.

Overall, a story emerges from these heterogeneity results. The effects of Rosenwald schools on incarceration are largely found in areas with strong judicial systems and where individuals were able to take advantage of higher education levels to avoid being incarcerated. For example, in a place with high anti-black sentiment, we might expect education not to matter for incarceration because blacks could be put in jail for any type of small infraction. Because incarceration is an outcome of (a) committing a crime; (b) being caught; and (c) being convicted, counties with more developed court systems and more educated populations seem to allow individuals to translate higher levels of education into lower incarceration rates.

D. Effects of Rosenwald schools on state prison admissions, arrests, and juvenile crime in North

\section{Carolina}

The benefit of the census data used thus far is that it provides a picture of all prisoners in the full South. A drawback is that it does not contain information about type of crime or sentence length, two characteristics that provide indirect information on whether and to what extent the racial gap in incarceration is simply due to the discriminatory Jim Crow legal system, rather than 
to "true" differences in criminal activity. One may think that exposure to Rosenwald schools reduced discrimination, which then led to less imprisonment in the local area.

In this section, I present estimates from different data sources that allow me to look more in detail at which mechanism is more likely. I focus on North Carolina and the specific details about the data are described in Appendix B.4. I first look at state prison reports which provide a flow measure of incarceration in each year. An additional benefit of this data is that state prisoners are more likely to have committed "real crimes," rather than, for example, being imprisoned due to enforcement of vagrancy laws, which was more likely to happen in local jails. Second, I examine county-level counts of court cases; this is a measure of the number of individuals accused of a crime, rather than only those convicted and sentenced for a crime. If the main effects derive from discrimination in conviction rates, due to partial juries or sentence lengths due to biased judges, I will not find an effect of Rosenwald schools on the case load. Following this, I look at juvenile court case data; because juveniles are rarely incarcerated but instead are put on probation, census data does not allow me to consider the contemporaneous effect of Rosenwald schools on youth activity.

\section{i. State Prison Reports and Attorney General Reports}

Results from the State Prison Reports are shown in Table 7. I create covariates based on the population census data in the decennial years and linearly extrapolate between years. Controls include the total black and white male populations, the total county population, the share of the population that is black, and the share of the population that lives in urban areas. I use the total number of prison intakes in a county and the log of intakes of the specific race as the outcome 
variables. ${ }^{34}$ Exposure is a weighted average based on the age distribution of prisoners and the timing of school openings in counties. ${ }^{35}$ I find that exposure to Rosenwald schools for one year would reduce the black-white gap in incarceration at the county level by five prisoners relative to a mean of 73 prisoners in column (1) or by 19 log points (20.9 percent) for a mean gap of $54 \log$ points in column (2).

An alternative measure of crime is the number of individuals accused of a crime in a given county in each year. I digitize county level court cases from the Attorney General reports from 1913-1935 (the data is not available in later years) and find that court cases against blacks also decrease by a similar magnitude with average exposure in a county. Results are shown in Table 8.

The results from the State Prison reports suggest that what I find in census data is not due to discrimination in sentence lengths or due to petty crimes. In fact, exposure to Rosenwald schools decreases the probability of being incarcerated in state prison. The fact that court cases go down as well suggests that arrests decrease with Rosenwald exposure. While I cannot rule out that court cases are related to discrimination at the arrest stage, this provides indirect evidence that my results are not due to discrimination at the sentencing stage.

\section{ii. Juvenile Court Data}

I consider contemporaneous effects of Rosenwald schools on the criminal activity of youth in Table 9. The observed decline in adult crime might arise because additional years of schooling increase the opportunity cost of crime. Alternatively, the main effect could be due to persistence

\footnotetext{
${ }^{34}$ County of birth is not available in this data so I use county of arrest. To the extent that there is migration from rural counties to urban counties, I will understate exposure since urban areas had fewer Rosenwald seats per student.

${ }^{35}$ Because the mean of the dependent variable increases by a factor of ten between 1933 and 1935, I restrict to post1935 in my analysis.
} 
of criminality: offenders who commit crimes at young ages often commit crimes later in life as well. If Rosenwald schools reduce crime among juveniles, these individuals might also be less likely to commit crimes later.

I do not have individual level data, but rather county-race counts for four five year periods. I regress the number of juvenile court cases for blacks or whites in a given county within a five year period on exposure to Rosenwald schools and the same set of county controls as above. Exposure is measured as the number of years over the previous five year period the county had a school. Exposure to Rosenwald schools has a negative and significant effect in all specifications. The effect of exposure on black juveniles is a decrease of 9.4 court cases per five years from the average of about 50 court cases. The effect of Rosenwald schools on white outcomes is insignificant and almost always small.

The magnitude of the effect on juvenile crime is very similar to that on adult crime in the census. If anything, it is larger relative to the mean. About 36 percent of juvenile offenders commit a crime at some point later in life (Illinois 2007). If we assume that these will happen in the next ten years and will require on average five years of incarceration (the average sentence length in the North Carolina state prison), then census data should capture 18 percent of repeat offenders; incarceration in census data therefore should decrease by about two percent of the mean $\left(=0.18^{*} 0.1\right)$. That means that the decrease in incarceration in census data could be partly due to the fact that kids have been kept out of a life of crime early on. However, most of the seven percent decrease in crime is likely due to less non-juvenile offenders. 


\section{Robustness}

In this section I turn to robustness measures and alternative specifications. I first discuss potential concerns about the sample and sources of variation that are driving my results. I also show that results are robust to different sets of county-year-race fixed effects and cohort trends. Then, I investigate non-linear effects of exposure and the hypothesis that there is a critical "age window" in which exposure to a Rosenwald school has the strongest effect on later-life outcomes. All regressions use the "likely seats" measure of exposure which is the number of years a child had a school in his county, weighted by the probability of having a seat available.

Table 10 contains results for nine regressions. One potential worry is that there are county time trends that might affect schooling and lower incarceration later in life. For example, if parents are becoming more literate over time in Rosenwald counties, then this could explain part of the effect. In row (2) I address this issue. I restrict to ages less than 30 since 30 to 35 year olds might not be a good comparison group for an 18 year old; the effect of exposure for blacks is slightly smaller for this group at -0.071 percentage points.

One issue with assigning Rosenwald exposure is how to handle schools that were built before 1919. These are referred to as the Tuskegee schools and unfortunately the year they were built is not available. I code students as being exposed if they were of the correct ages before 1919 all the way back to 1913 in these counties. However, we might worry that these counties are introducing substantial measurement error. I therefore drop these counties in row (3). I find that the results are stronger, if anything, when dropping these counties which make up 22 percent of the sample.

I next turn to showing that results are robust to different sets of fixed effects. I first include race-specific county fixed effects in row (4). This allows me to control for anything which is 
constant over time within a county but affects two races differently. Results do not change in this specification. I then add childhood census year-specific county fixed effects. Results are similar, meaning that any characteristics which are changing over time within counties and which affect both races similarly do not affect my results.

Finally, I consider the idea that there may be "smooth" underlying cohort trends which are not fully accounted for in my identification strategy. Rows (6) and (7) show that results are extremely similar when including state-specific cohort trends or county-specific cohort trends.

In Appendix C, I also show that results are similar if I use unmatched data from the 1940 full count census and assign exposure based on 1935 county of residence. I find that one year of exposure decreases the probability of being incarcerated by 0.048 percentage points, consistent with my results from Table 4.

\section{Conclusion}

This paper considers the social returns of a program which increased the schooling of black children between 1920 and 1940. The program was responsible for one year of the three year decrease in the black-white education gap in this time period. I show that the program also resulted in lower incarceration rates. I find a social return to a year of school of about a 0.4 percentage point decrease in incarceration, which is similar in magnitude to the literature but three times the size of contemporary estimates relative to the mean incarceration rate (Lochner and Moretti 2004).

This paper's results imply that the black-white incarceration gap should have decreased by half between 1910 and 1940. However, incarceration rates of blacks were increasing over this time period due to countervailing forces such as migration to the North (Muller 2012) and 
migration to cities within the South. However, it does not appear that Rosenwald schools themselves caused individuals to migrate to the North.

My results contribute to the broader scholarship about causes of black-white differentials in the $20^{\text {th }}$ century as well as to the literature on social returns to education. This is the first paper to consider social returns to education in a historical, developing economy environment; previous literature has considered social returns to schooling primarily in the contemporary United States and Europe where inequality is lower, institutions are stronger, and incomes and education levels are higher.

The historical gap between blacks and whites in incarceration is not well understood. This paper shows that differences in education were one factor that contributed to racial differences in crime and incarceration. Exploring the other causes of this gap would be a fruitful subject for future research. 


\section{Appendix A: Locations of Rosenwald Schools}

\section{A. Relationship between county characteristics and Rosenwald schools}

I consider the relationship between pre-Rosenwald county characteristics and the existence of a school. In Table B.1, I regress four outcomes on a set of race-specific socioeconomic variables and other demographic county variables. The outcomes are (a) whether the county ever had a Rosenwald school; (b) The total number of schools built in the county by the end of the program in 1931; (c) whether the county had a school before 1919; and (d) the number of years until the first school was built for counties which did get a school. I use literacy, school enrollment, and average occupational score as my socioeconomic variables. I also consider the effect of population density, the share of the population living in urban areas, the county's share of black and foreign born men, and the percentage of households that own a home. To account for the idea that distance from the Tuskegee Institute or other important historical black institutions might matter for the outcome variables, I include the distance from the center of the county to the Tuskegee Institute, Montgomery, AL, Nashville, TN, and Hampton, VA. Regressions also include state fixed effects and industry share controls by race. Finally, I consider the level of all of these variables in 1900 and 1910 and also the change between 1900 and 1910; that is, the share of the population that is urban might matter, but urbanizing counties might also be more or less likely to build a school.

In Panel A, I find a positive relationship between black literacy and ever having a Rosenwald school. A ten percentage point increase in black literacy in 1910 would increase the probability of having a school by 2.2 percentage points. The coefficients on white literacy are almost twice as large but insignificant. There is also some evidence that counties with higher population density and urbanizing counties with increasing urban share between 1900 and 1910 were more likely to get a school. In Panel B, the number of schools built by 1931 is positively correlated with population density, black literacy, the percent of farmers who are black, and the total number of farms in the county. Counties which built a school before 1919, in Panel C, tended to have a lower percentage of black farms, higher white literacy, a higher percentage of black men, and lower percentage of black owner-occupier farmers. Counties where 
home ownership or the percentage of black farmers were growing were less likely to get a school before 1919. Finally, in Panel D, we see that counties with increasing population density or increases in the share foreign born waited fewer years before a school was built. Those with higher black literacy also waited fewer years. The percentage of black farmers is positively correlated with the number of years until the first school was built.

I next consider whether the variables that I use in my heterogeneity tables (Tables 6, 7, and 8) predict Rosenwald outcomes. In Table B.2, I regress the same outcome variables on a set of variables which might predict Rosenwald school location and coverage. I use lynchings and executions per 100,000 population. I find a negative relationship between these and Rosenwald schools, if anything, suggesting that places with more lynchings built fewer Rosenwald schools. This is consistent with a picture of a county indifferent to both incarceration and schooling. I also include county per capita expenditures from 1902 on a range of categories, including jails and courts. I find that places which spent more on jails in the pre-Rosenwald period built fewer schools by 1931. This is the opposite of what we would expect if counties which were very worried about crime also built more schools. Finally, counties with a higher share of the vote for the Democratic candidate in 1948, and therefore lower vote shares for Strom Thurmond, were less likely to build a school in the Rosenwald period and built fewer schools. Again, this goes against the idea that places with high racial antipathy voted for Strom Thurmond and also built fewer schools.

\section{B. Family migration decisions and Rosenwald schools}

Another concern is that families who were more literate or of higher socio-economic status may have migrated towards counties with Rosenwald schools. In that case, we would expect average income and literacy of individuals not directly affected by the Rosenwald schools to increase in a county after the introduction of the schools. That is, average literacy in a county with high exposure to the schools should increase more than that of counties with low exposure to the school if literate parents migrate towards 
schools for their children. If literate parents have children who are unlikely to be incarcerated, this might bias my results.

To examine this, I regress literacy of men ages 30 to 50 on indicators for county Rosenwald exposure in various years of the previous decade. Because the data is noisy, I group it into three categories: exposure 1-3 years earlier (rose1), exposure 4-6 years earlier (rose2), and exposure 7-9 years earlier (rose3). I interact each exposure measure with a dummy variable for being black. I would worry about selective migration if these interaction terms are significant. The results are shown in Table B.3. I find no significant evidence that there was selective in-migration to Rosenwald counties of more literate families between census years. There is some weak evidence $(\mathrm{p}=0.09)$ that Rosenwald exposure in the previous three years is associated with higher occupational scores of men in this age range, but this test is less clean; it is reasonable that Rosenwald schools could have increased wages for men so this is not direct evidence of selective migration. 
Table A.1: Correlation between 1900 and 1910 county characteristics and Rosenwald schools

\begin{tabular}{|c|c|c|c|c|c|c|}
\hline \multirow[b]{3}{*}{ Pop density } & \multicolumn{3}{|c|}{ (a) Ever had a Rosenwald school } & \multicolumn{3}{|c|}{ (b) Number of schools, 1931} \\
\hline & 1900 & 1910 & Change & 1900 & 1910 & Change \\
\hline & $\begin{array}{c}0.075 \\
(0.137)\end{array}$ & $\begin{array}{c}0.329 * * \\
(0.115)\end{array}$ & $\begin{array}{c}0.085 \\
(0.076)\end{array}$ & $\begin{array}{c}3.038 * * * \\
(0.980)\end{array}$ & $\begin{array}{l}5.273 * * \\
(1.981)\end{array}$ & $\begin{array}{l}3.071 * \\
(1.581)\end{array}$ \\
\hline$\%$ Black & $\begin{array}{c}1.305 \\
(0.363)\end{array}$ & $\begin{array}{l}1.144 * * \\
(0.424)\end{array}$ & $\begin{array}{c}0.371 \\
(0.439)\end{array}$ & $\begin{array}{c}3.753 \\
(2.971)\end{array}$ & $\begin{array}{c}-0.088 \\
(3.195)\end{array}$ & $\begin{array}{c}13.373^{* *} \\
(5.057)\end{array}$ \\
\hline \% Urban & $\begin{array}{c}-0.0005 \\
(0.109)\end{array}$ & $\begin{array}{c}0.116 \\
(0.087)\end{array}$ & $\begin{array}{c}0.526^{* * *} \\
(0.161)\end{array}$ & $\begin{array}{c}1.111 \\
(2.105)\end{array}$ & $\begin{array}{c}1.282 \\
(1.708)\end{array}$ & $\begin{array}{c}7.438 * * \\
(2.831)\end{array}$ \\
\hline \% Foreign-born & $\begin{array}{l}-0.245 \\
(0.669)\end{array}$ & $\begin{array}{c}0.572 \\
(0.662)\end{array}$ & $\begin{array}{c}0.843 \\
(0.846)\end{array}$ & $\begin{array}{l}-4.473 \\
(4.871)\end{array}$ & $\begin{array}{l}-2.940 \\
(5.905)\end{array}$ & $\begin{array}{c}9.643 \\
(16.76)\end{array}$ \\
\hline \% Own home & $\begin{array}{c}0.564 \\
(0.103)\end{array}$ & $\begin{array}{c}0.715^{* * *} \\
(0.154)\end{array}$ & $\begin{array}{l}-0.128 \\
(0.259)\end{array}$ & $\begin{array}{l}-3.556 \\
(3.195)\end{array}$ & $\begin{array}{c}2.404 \\
(3.421)\end{array}$ & $\begin{array}{c}4.180 \\
(3.134)\end{array}$ \\
\hline \% Lit White & $\begin{array}{c}0.714 \\
(0.369)\end{array}$ & $\begin{array}{c}0.745 \\
(0.455)\end{array}$ & $\begin{array}{l}-0.869 \\
(0.623)\end{array}$ & $\begin{array}{c}1.427 \\
(5.291)\end{array}$ & $\begin{array}{c}1.051 \\
(7.369)\end{array}$ & $\begin{array}{l}-6.861^{*} \\
(3.668)\end{array}$ \\
\hline \% Lit Black & $\begin{array}{c}0.462 \\
(0.114)\end{array}$ & $\begin{array}{c}0.224 * * \\
(0.095)\end{array}$ & $\begin{array}{l}-0.138 \\
(0.101)\end{array}$ & $\begin{array}{l}3.056 * \\
(1.551)\end{array}$ & $\begin{array}{l}3.507^{*} \\
(1.881)\end{array}$ & $\begin{array}{c}2.449 \\
(1.743)\end{array}$ \\
\hline \# farms (1000s) & $\begin{array}{c}0.0053 \\
(0.0021)\end{array}$ & $\begin{array}{c}0.004^{* *} \\
(0.001)\end{array}$ & $\begin{array}{c}0.005 \\
(0.003)\end{array}$ & $\begin{array}{c}0.124 \\
(0.034)\end{array}$ & $\begin{array}{c}0.124^{* * * *} \\
(0.020)\end{array}$ & $\begin{array}{c}0.264^{* * *} \\
(0.056)\end{array}$ \\
\hline$\%$ farms black & $\begin{array}{c}-0.344 \\
(0.151)\end{array}$ & $\begin{array}{l}-0.436 \\
(0.319)\end{array}$ & $\begin{array}{c}-0.497 * * * \\
(0.116)\end{array}$ & $\begin{array}{c}3.396 * * * \\
(2.054)\end{array}$ & $\begin{array}{l}10.712 \\
(3.971)\end{array}$ & $\begin{array}{c}-10.949 * * * \\
(2.116)\end{array}$ \\
\hline $\begin{array}{l}\text { \% black farmers } \\
\text { who own }\end{array}$ & $\begin{array}{l}-0.083 \\
(0.087)\end{array}$ & $\begin{array}{l}-0.062 \\
(0.046)\end{array}$ & $\begin{array}{l}-0.046 \\
(0.084)\end{array}$ & $\begin{array}{l}-1.425 \\
(0.852)\end{array}$ & $\begin{array}{l}-0.754 \\
(0.683)\end{array}$ & $\begin{array}{c}0.365 \\
(0.724)\end{array}$ \\
\hline $\begin{array}{l}\text { \% white farmers } \\
\text { who own }\end{array}$ & $\begin{array}{l}-0.228 \\
(0.221)\end{array}$ & $\begin{array}{l}-0.513^{*} \\
(0.235)\end{array}$ & $\begin{array}{l}-0.061 \\
(0.262)\end{array}$ & $\begin{array}{l}7.556 * * \\
(2.645)\end{array}$ & $\begin{array}{l}-1.375 \\
(3.291)\end{array}$ & $\begin{array}{l}-7.571 \\
(4.419)\end{array}$ \\
\hline $\begin{array}{l}\text { Sample Mean } \\
\text { N } \\
\text { R-squared }\end{array}$ & $\begin{array}{c}0.65 \\
1,088 \\
0.3998\end{array}$ & $\begin{array}{c}0.65 \\
1,154 \\
0.3929\end{array}$ & $\begin{array}{c}0.65 \\
1,067 \\
0.3593\end{array}$ & $\begin{array}{c}3.495 \\
1,088 \\
0.4214\end{array}$ & $\begin{array}{c}3.495 \\
1,154 \\
0.4548\end{array}$ & $\begin{array}{c}3.495 \\
1,067 \\
0.4226\end{array}$ \\
\hline
\end{tabular}

Notes: All regressions control for industry shares by race and include state fixed effects. They also control for distance from the center of the county to Tuskegee Institute, Hampton, Virginia, Montgomery, AL, and Nashville, TN. Standard errors are clustered at the state level. 
Table A.1 (cont): Correlation between 1900 and 1910 county characteristics and Rosenwald schools

\begin{tabular}{|c|c|c|c|c|c|c|}
\hline \multirow[b]{3}{*}{ Pop density } & \multicolumn{3}{|c|}{ (c) Has a school by 1919} & \multicolumn{3}{|c|}{ (d) Years until first school } \\
\hline & 1900 & 1910 & Change & 1900 & 1910 & Change \\
\hline & $\begin{array}{c}0.162 \\
(0.110)\end{array}$ & $\begin{array}{c}0.277 \\
(0.167)\end{array}$ & $\begin{array}{c}0.125 \\
(0.083)\end{array}$ & $\begin{array}{c}0.261 \\
(1.809)\end{array}$ & $\begin{array}{c}2.460 \\
(3.648)\end{array}$ & $\begin{array}{c}-5.988 * * \\
(2.298)\end{array}$ \\
\hline \% Black & $\begin{array}{c}0.781^{* * *} \\
(0.259)\end{array}$ & $\begin{array}{c}0.340 \\
(0.377)\end{array}$ & $\begin{array}{c}0.205 \\
(0.402)\end{array}$ & $\begin{array}{l}-5.061 \\
(4.319\end{array}$ & $\begin{array}{c}-2.664 \\
(2.905)\end{array}$ & $\begin{array}{c}-1.297 \\
(1.946)\end{array}$ \\
\hline \% urban & $\begin{array}{c}0.166 \\
(0.122)\end{array}$ & $\begin{array}{c}0.217 * * \\
(0.097)\end{array}$ & $\begin{array}{c}0.278 \\
(0.192)\end{array}$ & $\begin{array}{c}-0.292 \\
(0.931)\end{array}$ & $\begin{array}{l}-0.429 \\
(0.764)\end{array}$ & $\begin{array}{c}-1.329 \\
(2.231)\end{array}$ \\
\hline \% Foreign-born & $\begin{array}{c}-0.487 \\
(0.301)\end{array}$ & $\begin{array}{c}-0.298 \\
(0.355)\end{array}$ & $\begin{array}{c}0.448 \\
(1.235)\end{array}$ & $\begin{array}{c}5.780 \\
(4.107)\end{array}$ & $\begin{array}{c}1.365 \\
(6.544)\end{array}$ & $\begin{array}{c}-13.026^{*} \\
(7.144)\end{array}$ \\
\hline \% Own home & $\begin{array}{c}0.151 \\
(0.112)\end{array}$ & $\begin{array}{c}-0.011 \\
(0.289)\end{array}$ & $\begin{array}{c}-0.482^{* *} \\
(0.222)\end{array}$ & $\begin{array}{c}-2.026 \\
(1.845)\end{array}$ & $\begin{array}{c}-2.034 \\
(1.683)\end{array}$ & $\begin{array}{c}2.500 \\
(1.891)\end{array}$ \\
\hline \% Lit White & $\begin{array}{c}0.225 \\
(0.231)\end{array}$ & $\begin{array}{c}0.534^{* * *} \\
(0.170)\end{array}$ & $\begin{array}{c}-0.504 \\
(0.391)\end{array}$ & $\begin{array}{c}1.211 \\
(3.207)\end{array}$ & $\begin{array}{c}2.851 \\
(2.441)\end{array}$ & $\begin{array}{c}4.051 \\
(5.819)\end{array}$ \\
\hline \% Lit Black & $\begin{array}{c}0.154 \\
(0.112)\end{array}$ & $\begin{array}{c}0.093 \\
(0.158)\end{array}$ & $\begin{array}{c}0.196 \\
(0.195)\end{array}$ & $\begin{array}{c}-2.179 \\
(2.541)\end{array}$ & $\begin{array}{c}-3.932 * \\
(1.866)\end{array}$ & $\begin{array}{l}-3.458 * \\
(1.930)\end{array}$ \\
\hline \# farms (thousands) & $\begin{array}{c}0.005 * * \\
(0.003)\end{array}$ & $\begin{array}{c}0.004^{* *} \\
(0.002)\end{array}$ & $\begin{array}{c}0.006^{* *} \\
(0.003)\end{array}$ & $\begin{array}{c}-0.052^{* * *} \\
(0.014)\end{array}$ & $\begin{array}{c}-0.042 * * * \\
(0.013)\end{array}$ & $\begin{array}{c}-0.058 * \\
(0.029)\end{array}$ \\
\hline Proportion farms black & $\begin{array}{c}-0.166^{*} \\
(0.085)\end{array}$ & $\begin{array}{c}0.033 \\
(0.265)\end{array}$ & $\begin{array}{c}-0.459 * * * \\
(0.129)\end{array}$ & $\begin{array}{c}0.157 \\
(1.475)\end{array}$ & $\begin{array}{c}-1.842 \\
(2.414)\end{array}$ & $\begin{array}{c}3.031^{* * *} \\
(0.598)\end{array}$ \\
\hline $\begin{array}{l}\text { \% black farmers who } \\
\text { own }\end{array}$ & $\begin{array}{c}-0.141^{* *} \\
(0.059)\end{array}$ & $\begin{array}{l}-0.016 \\
(0.044)\end{array}$ & $\begin{array}{l}-0.012 \\
(0.039)\end{array}$ & $\begin{array}{l}-0.670 \\
(0.808)\end{array}$ & $\begin{array}{l}-0.573 \\
(0.541)\end{array}$ & $\begin{array}{l}-0.084 \\
(1.639)\end{array}$ \\
\hline $\begin{array}{l}\text { \% white farmers who } \\
\text { own }\end{array}$ & $\begin{array}{c}0.232 \\
(0.188)\end{array}$ & $\begin{array}{l}-0.110 \\
(0.213)\end{array}$ & $\begin{array}{l}-0.337 \\
(0.188)\end{array}$ & $\begin{array}{l}-2.091 \\
(1.643)\end{array}$ & $\begin{array}{l}-0.202 \\
(1.845)\end{array}$ & $\begin{array}{c}2.516 \\
(2.148)\end{array}$ \\
\hline $\begin{array}{l}\text { Sample Mean } \\
\text { N } \\
\text { R-squared }\end{array}$ & $\begin{array}{c}0.225 \\
1,088 \\
0.2963\end{array}$ & $\begin{array}{c}0.225 \\
1,154 \\
0.3003\end{array}$ & $\begin{array}{c}0.225 \\
1,067 \\
0.2789\end{array}$ & $\begin{array}{c}3.153 \\
782 \\
0.2682\end{array}$ & $\begin{array}{c}3.153 \\
767 \\
0.2685\end{array}$ & $\begin{array}{c}3.153 \\
781 \\
0.2553\end{array}$ \\
\hline
\end{tabular}

Notes: All regressions control for industry shares by race and include state fixed effects. They also control for distance from the center of the county to Tuskegee Institute, Hampton, Virginia, Montgomery, AL, and Nashville, TN. Standard errors are clustered at the state level. 
Table A.2: Correlation between county characteristics and Rosenwald schools

\begin{tabular}{|c|c|c|c|c|}
\hline & (1) & $(2)$ & (3) & (4) \\
\hline & Ever Had a School & $\begin{array}{c}\text { Number of Schools } \\
\text { by } 1931 \\
\end{array}$ & $\begin{array}{c}\text { Had a school by } \\
1919 \\
\end{array}$ & $\begin{array}{l}\text { Number of Years } \\
\text { until First School }\end{array}$ \\
\hline Lynchings PC & $\begin{array}{l}-0.0016 \\
(0.001)\end{array}$ & $\begin{array}{c}-0.0350 * * \\
(0.016)\end{array}$ & $\begin{array}{l}-0.0021 \\
(0.001)\end{array}$ & $\begin{array}{l}0.0304 * \\
(0.015)\end{array}$ \\
\hline \# of years dry since 1900 & $\begin{array}{l}0.0034 \\
(0.003)\end{array}$ & $\begin{array}{l}0.0622 \\
(0.049)\end{array}$ & $\begin{array}{l}0.0076 \\
(0.005)\end{array}$ & $\begin{array}{l}-0.0365 \\
(0.027)\end{array}$ \\
\hline Jails Expenditures PC & $\begin{array}{l}0.2069 \\
(0.181)\end{array}$ & $\begin{array}{l}-5.2417 * \\
(2.604)\end{array}$ & $\begin{array}{l}0.0008 \\
(0.415)\end{array}$ & $\begin{array}{l}2.5451 \\
(5.417)\end{array}$ \\
\hline Court Expenditures PC & $\begin{array}{l}-0.1257 \\
(0.127)\end{array}$ & $\begin{array}{l}0.8198 \\
(1.872)\end{array}$ & $\begin{array}{l}-0.2380 \\
(0.140)\end{array}$ & $\begin{array}{l}0.5269 \\
(0.816)\end{array}$ \\
\hline Share Dem Vote, 1948 & $\begin{array}{c}-0.0003 * * * \\
(0.000)\end{array}$ & $\begin{array}{c}-0.0014^{* *} \\
(0.001)\end{array}$ & $\begin{array}{l}0.0000 \\
(0.000)\end{array}$ & $\begin{array}{l}0.0004 \\
(0.000)\end{array}$ \\
\hline Total Expenditures PC & $\begin{array}{l}0.0323 \\
(0.026)\end{array}$ & $\begin{array}{l}-0.1275 \\
(0.212)\end{array}$ & $\begin{array}{l}0.0004 \\
(0.017)\end{array}$ & $\begin{array}{l}0.0810 \\
(0.179)\end{array}$ \\
\hline Baptists per 100000 & $\begin{array}{l}-0.0838 \\
(0.193)\end{array}$ & $\begin{array}{l}-0.6971 \\
(1.846)\end{array}$ & $\begin{array}{l}0.2272 \\
(0.160)\end{array}$ & $\begin{array}{l}-1.3286 \\
(1.431)\end{array}$ \\
\hline Observations & 740 & 740 & 740 & 593 \\
\hline R-squared & 0.295 & 0.399 & 0.298 & 0.254 \\
\hline
\end{tabular}

Notes: All regressions control for total population, the share of population that is black, population density, and industry shares by race and include state fixed effects. They also control for distance from the center of the county to Tuskegee Institute, Hampton, Virginia, Montgomery, AL, and Nashville, TN. Standard errors are clustered at the state level. 
Table A.3: Selective migration of literate and higher occupational status families to Rosenwald Counties

\begin{tabular}{l|cccc}
\hline Outcome: & Literacy & Literacy & Occupational Score & Occupational Score \\
\hline Black*Rose1 & 0.011 & -0.017 & 0.927 & $2.097 *$ \\
& $(0.018)$ & $(0.018)$ & $(0.769)$ & $(1.221)$ \\
Black*Rose2 & & & & \\
& -0.005 & 0.031 & -0.145 & -0.900 \\
Black*Rose3 & $(0.029)$ & $(0.032)$ & $(0.855)$ & $(1.245)$ \\
& & & -0.632 & -0.619 \\
Rose1 & 0.004 & -0.037 & $(0.502)$ & $(0.686)$ \\
& $(0.025)$ & $(0.036)$ & & -0.746 \\
Rose2 & -0.002 & 0.006 & 0.042 & $(0.490)$ \\
& $(0.007)$ & $(0.006)$ & $(0.257)$ & 0.846 \\
Rose3 & & & $-0.505)$ \\
& 0.013 & 0.004 & & \\
Ages & $(0.010)$ & $(0.010)$ & $(0.405)$ & -0.302 \\
R-squared & & & & \\
$\mathrm{N}$ & $-0.019 * *$ & -0.011 & 0.169 & \\
\hline
\end{tabular}

Notes: regressions include fixed effects for age, black*age, year, state*year, and county. I restrict to men living in rural areas in the census year since schools were targeted to rural areas. 


\section{Appendix B: Data}

\section{B.1 Extracting Prisoners from the 1920, 1930, and 1940 US Censuses}

Because the 1940 census is available in fully digitized form at the National Bureau of Economic Research, I handle the 1920 and 1930 censuses differently than the 1940 census. My approach to finding prisoners in all three censuses is described below.

\section{B.1.i: 1920 and 1930}

I begin with the full indexes of the 1920, and 1930 censuses from FamilySearch.org. These indexes include information which includes name, age, race, marital status, and relationship to household head. They do not, in general, include the name of the institution if an individual is incarcerated. Next, I extract all men between the ages of 18 and 35 who report a relationship to household head of "Prisoner". These men are definitely in a federal, state, or county prison. However, not everyone who is in a prison is called a "Prisoner". For example, in 1920 the North Carolina State Prison all individuals had blank relationships to household head. These will not show up in this first pass. Therefore, I then extract every man in the relevant age range who is either an "Inmate" or who has a blank relationship. I start with 52,715 prisoners, 55,780 “inmates”, and 132,743 with a blank relationship.

I then define two initial rules to determine likely prisoners.

1. If the census page has more than 20 percent women or 20 percent children under age 15, I drop that page from my set of possible prison matches.

2. If the census page has mostly men over age 55, I expect that it is an old age home and so I drop that page as well.

After this procedure, I then look for pages with multiple inmates or missing individuals. Due to time constraints, I define a rule which determines which pdf images to look at by hand: if the image has more than 10 individuals with a blank relationship or has more than 1 "Inmate”, then I keep it. This results in 31 percent of the possible pages but 67 percent of the blank and inmate observations. Blank relationship observations are often found in hotels or railroad camps and are half as likely to be prisoners as “Inmates”. 
At the end of this process, I look up 8,733 and 10,864 sheets from 1920 and 1930, respectively. This covers 258,790 individuals from 1920 and 423,637 from 1930. After identifying the set of likely prisoners, I code each image by hand. The resulting dataset identifies an additional 10,157 prisoners in 1920 and 26,339 in 1930 in the relevant age range and birth states. I pool this with the 13,853 and 38,862 prisoners identified as "Prisoner" in the 1920 and 1930 censuses, respectively. Through this process, I also code the institution name so that I can restrict to prisoners in state and federal prisons rather than local jails. Unfortunately, for those who are identified as "Prisoner”, I do not know the institution name.

\section{B.1.ii: 1940}

The full 1940 census is available in digital form on the National Bureau of Economic Research server. I first extract possible prisoners from the 1940 FamilySearch.org index in a similar way to above, and then attach these to the full census on the server to determine the institution for those who are “inmates” or have a blank relationship. I use the institution name which is digitized to identify those in jail or prison. While Moehling and Piehl (2014) restrict only to those in state and federal prisons, I do consider those in jail in my primary analysis. One main reason is that the state prison systems in the South were less developed than in the North in this time period. In the North, 86.4 percent of prisoners were in state or federal prisons in this census, but in the South it was only 80.5 percent. These numbers are more different in previous census waves. Also, in the South, average jail sentence lengths were about two years which suggests jails were used to house long-term prisoners (Oshinsky 1996).

I find 13,032 prisoners who are called "Prisoner”, 25,299 of 45,057 who were called inmates are actually in prison, and 35,989 of 155,131 who had blank relationships and are in prison. Because some enumerators did not write the name of the institution on the correct line, I find that 39,406 of the 155,131 inmate/blanks do not have an institution name. Therefore, I use the same rules as above to define which pdf images to look at. I find an additional 9,002 prisoners from 1,914 images.

My final prisoner sample has 172,533 prisoners. The incarceration rates are 0.32 percent, 0.95 percent, and 1.15 percent in 1920, 1930, and 1940 respectively. I then match this sample back to a previous census wave. This procedure is described in the next section. 


\section{B.2 Matching}

The matching procedure starts with the base year of 1920, 1930, or 1940 and matches backwards to either 10 or 20 years prior. The procedure is as follows:

(1) For both censuses which will be matched to each other, I begin by standardizing the first and last names of men in the later year to address orthographic differences between phonetically equivalent names using the NYSIIS algorithm (Atack and Bateman 1992). I also recode any common nicknames to standard first names (e.g. Will becomes William). I restrict my attention to men in the respective census that are unique by first and last name, birth year, race, and state of birth. I do so because, for non-unique cases, it is impossible to determine which of the records should be linked to potential matches in the earlier year. For my primary sample, I further restrict individuals to be unique within a five year age band. That is, each individual only remains in the sample if there is no one with the same first and last name, birth state, and race who reports a birth year within two years of that individual. This prioritizes accuracy over sample size, but minimizes measurement error in the final dataset.

(2) I match observations backwards from the later year to the earlier year using an iterative procedure. I start by looking for a match by first name, last name, race, state of birth, and exact birth year. There are three possibilities:

(a) if I find a unique match within the five year age band, I stop and consider the observation "matched";

(b) if I find multiple matches for the individual within the five year band, the observation is thrown out;

(c) if I do not find a match at this first step, I try allowing the individual's age to be "off” by one year in either direction. Then, if this does not result in a match, I allow the age to be "off" by two years in either direction. I only accept unique matches. If none of these attempts produces a match, the observation is discarded as unmatched. 
My matching procedure generates a final sample of 25,204 prisoners and 617,935 non-prisoners. Conditional on being unique within a 5-year age band, I can successfully match 45.02 percent of all prisoners and 26.28 percent of non-prisoners. The difference between these match rates is most likely due to the fact that prisoners are less likely to be unique within a 5 year band. Conditional on being unique, they are more likely to match. I have lower match rates for blacks than for whites, which is consistent with lower education levels. Table A.1 presents sample sizes and match rates by adult year, prisoner status, and race. Because the 1940 census index is of higher quality, match rates are consistently higher for this year. Match rates are lower for non-prisoners and lowest in 1920. To account for the substantial differences in match rates across years, I create sample weights based on the match rates by prisoner status, year, and race. This enables me to interpret the coefficients relative to the correct incarceration rate for each year and race.

Individuals can fail to match due to (i) non-unique name-birthplace-race combinations; (ii) misreporting of age; and (iii) complete misspellings of the name. Note that mortality cannot account for any failure to match due to starting with the later year and matching backwards. Non-unique combinations in the later year account for about 52 percent of match failures. Allowing individuals to match within a 10 year age range gains an additional 10 percent so these are likely misreported ages. Finally, individuals who cannot be found because of differences in name spellings account for the remaining 38 percent. Note that this could be because the individual misspelled their name (likely correlated with education, etc) or because the enumerator or the modern transcriber misspelled it (random). In fact, the match rate between the census indexes of Ancestry.com and FamilySearch.org is quite low at around 65 percent, suggesting that a lot of the differences in spelling are due to transcription differences in the index.

Another concern is whether the matched dataset is representative of the population. Most literature (Abramitzky, et al 2012) finds that the matched sample has slightly higher socio-economic status than the full population. I explore this possibility with the 1940 census here. This is the only census for which I have enough information digitized to compare the matched and unmatched samples. As noted above, the census indexes from 1920 and 1930 do not have literacy, home ownership, or 
occupation/income. Table A.2 compares the matched sample to the 1940 population by prisoner status and race. I compare the matched set of prisoners to the full set of prisoners and the matched set of nonprisoners to the relevant age-race-birthplace set from the 1940 Ipums 1 percent sample.

I find that the matched sample has slightly higher education and income levels. For white nonprisoners, education levels are 0.19 years higher in the matched sample than full Ipums population. Yearly income is $\$ 63.33$ higher in the matched sample, relative to a population average of $\$ 798$. For black non-prisoners, matched men have 0.42 more years of school and a statistically insignificant \$5.84 more income. For both groups, income is more likely to be missing in the matched sample. This is most likely because the 1940 census index is messy and some income is not cleanly coded so it is missing in general more here than in the Ipums sample. Among prisoners, income is not available so I look at education levels. I find that black matched prisoners have slightly higher education levels than the population of black prisoners, but that white matched prisoners actually have lower education than the population of white prisoners.

\section{B.3: Heterogeneity}

I use data from multiple other sources to examine whether the effect of Rosenwald schools depends on local county characteristics. Compulsory schooling laws might augment the effect of new school construction. Rosenwald schools likely made schools available in areas where children could not attend school so I expect that a Rosenwald school in an area with compulsory schooling would have a larger effect on literacy/human capital and therefore a larger effect on incarceration than one somewhere without compulsory schooling laws. I find some evidence for this hypothesis.

I also look at effects that differ by county economic characteristics, including measures of white and black socioeconomic status, the share of farming on plantations, and the extent of slavery in the county before the Civil War (Aaronson and Mazumder 2011). I also consider effects depending on patterns of lynching (Project HAL 2014), executions (ICPSR \#8451), prohibition (ICPSR \#8343), and voting patterns in the 1948 Presidential election (ICPSR \#8611). I define a variable equal to one if the 
county had a lynching in the 40 years prior to 1920. A similar variable is defined equal to one if the county convicted more than one executed prisoner in the same time period. I consider counties which had been dry counties for more than ten years before 1920 and compare these to counties which had not been dry for more than ten years. Finally, I use vote shares for Strom Thurmond from the presidential election in 1948 as a measure of anti-civil rights sentiment. I expect that results may be stronger in counties with lower vote shares for Strom Thurmond.

The correlations between my heterogeneity variables are shown in Table B.3. The most interesting correlations in the bottom row show that the Thurmond vote share is correlated with areas with large black populations and where a large share of the population were slaves in 1860. This is unsurprising because Thurmond was the main Democrat candidate in the Deep South states of Alabama, Mississippi, Georgia, and Louisiana. As expected, the Thurmond vote share is positively correlated with lynching since both of these are measures of racial antipathy.

\section{B.4: North Carolina Additional Data}

One drawback to using census data on incarceration to measure crime is that they do not include information about the severity of the crime or length of the sentence. Furthermore, a count of individuals in prison at a point in time captures mostly new criminals, not all individuals who have been engaged in criminal activity in the past (who may have since been released from prison).

I collect complete county-race-year counts of inmates admitted to the North Carolina State Prison from the State Prison reports between 1930 and 1955. This data allows me to measure the flow of prisoners into prison rather than the stock. I assign exposure as the weighted average of exposure of individuals based on the age distribution of admissions. That is, I calculate the number of years individuals of each age would have had a school in their county and then take the weighted average based on the age distribution of admissions which is available aggregated to the state level. The number of 
admissions increases almost tenfold between 1933 and 1935 so I restrict to post-1935. ${ }^{36}$ Prior to 1931 , data is not available broken down by race.

Because juvenile delinquents were so infrequently incarcerated, they are unlikely to show up in the census data. ${ }^{37}$ Children had to be at least 16 years of age to be sent to a state prison. I use county-level data on juvenile court cases by race coded by Wiley Britton Sanders (1945) to estimate the effect of the Rosenwald program on juvenile delinquency. I have eight data points per county: separate counts for black and white children for the time periods $1919-29^{38}, 1929-34,1934-39$ and 1939-44. Ideally, one would use annual data to trace out the effect of a new Rosenwald school but the underlying data from which Sanders constructed his series appears to be lost. I calculate average exposure for each county in the time period and assign this to the relevant data point. More specifically, the exposure measure is calculated as the number of years in this time period that the county had a school.

\footnotetext{
${ }^{36}$ This seems to be because in the early periods the state prison reports only reported people who were sentenced to the state prison and not to road camps; data after this includes prisoners at state prison camps and road construction gangs outside of the state prison which made up a large proportion of prisoners.

${ }^{37}$ Juvenile court systems were not organized on a systematic basis until the 1930's and any incarceration facilities were small at best. For examples, North Carolina had only two "training schools" to which judges could send juvenile delinquents. One for whites, called the Morrison Training school, was established in 1918 but had only 30 places. It wasn't until 1925 that a facility was built for black children. The Stonewall Jackson school had room for 35 students.

${ }^{38}$ I divide these counts by two to get a comparable 5 year count.
} 
Table B.1: Sample sizes and match rates

\begin{tabular}{|c|c|c|c|c|c|c|}
\hline & & $\begin{array}{c}(1) \\
\text { Full Sample }\end{array}$ & $\begin{array}{c}\text { (2) } \\
\text { Unique within } \\
5 \text { year band }\end{array}$ & $\begin{array}{c}\text { (3) } \\
\text { Matched }\end{array}$ & $\begin{array}{c}\text { (4) } \\
\text { Match Rate } \\
\text { (Full Pop) }\end{array}$ & $\begin{array}{c}\text { (4) } \\
\text { Match rate } \\
\text { (Unique) }\end{array}$ \\
\hline \multicolumn{7}{|l|}{1940} \\
\hline \multicolumn{7}{|c|}{ Prisoners } \\
\hline & Black & 31,034 & 13,755 & 4,999 & 0.161 & 0.364 \\
\hline & White & 30,254 & 13,392 & 8,144 & 0.269 & 0.612 \\
\hline \multicolumn{7}{|c|}{ Non-Prisoners } \\
\hline & Black & 307,784 & 178,386 & 55,302 & 0.179 & 0.310 \\
\hline & White & 908,946 & 588,945 & 369,519 & 0.406 & 0.627 \\
\hline \multicolumn{7}{|l|}{1930} \\
\hline \multicolumn{7}{|c|}{ Prisoners } \\
\hline & Black & 26,797 & 12,521 & 3,799 & 0.141 & 0.303 \\
\hline & White & 24,621 & 11,847 & 7,054 & 0.286 & 0.597 \\
\hline \multicolumn{7}{|c|}{ Non-Prisoners } \\
\hline & Black & 318,686 & 209,194 & 18,552 & 0.058 & 0.088 \\
\hline & White & 756,610 & 692,903 & 91,229 & 0.120 & 0.144 \\
\hline \multicolumn{7}{|l|}{1920} \\
\hline \multicolumn{7}{|c|}{ Prisoners } \\
\hline & Black & 6,350 & 3,210 & 711 & 0.111 & 0.221 \\
\hline & White & 2,656 & 1,258 & 497 & 0.187 & 0.395 \\
\hline \multicolumn{7}{|c|}{ Non-Prisoners } \\
\hline & Black & 231,774 & 142,034 & 11,793 & 0.051 & 0.082 \\
\hline & White & 617,045 & 539,198 & 71,540 & 0.115 & 0.132 \\
\hline
\end{tabular}

Notes: Prisoners and non-prisoners are taken from the census indexes provided by FamilySearch.org. I take a twenty percent sample of non-prisoners and a full 100 percent sample of prisoners. Individuals are matched based on name, age, state of birth, and race. 
Table B.2: Comparing the matched sample to the full population, 1940

\begin{tabular}{|c|c|c|c|c|c|c|}
\hline & \multicolumn{3}{|c|}{ Full Population } & \multicolumn{3}{|c|}{ Matched Sample - Full Population } \\
\hline & Educ. & Income & $\begin{array}{l}\text { Missing } \\
\text { Income }\end{array}$ & Educ. & Income & $\begin{array}{l}\text { Missing } \\
\text { Income }\end{array}$ \\
\hline Prisoners & & & & & & \\
\hline Black & $\begin{array}{c}5.541 \\
(3.421)\end{array}$ & & & $\begin{array}{c}0.230 * * * \\
(0.073)\end{array}$ & & \\
\hline White & $\begin{array}{c}7.489 \\
(3.422)\end{array}$ & & & $\begin{array}{c}-0.439 * * * \\
(0.051)\end{array}$ & & \\
\hline $\begin{array}{l}\text { Non- } \\
\text { Prisoners }\end{array}$ & & & & & & \\
\hline Black & $\begin{array}{c}5.837 \\
(3.298)\end{array}$ & $\begin{array}{c}430.89 \\
(354.40)\end{array}$ & $\begin{array}{c}0.328 \\
(0.469)\end{array}$ & $\begin{array}{c}0.421^{* * *} \\
(0.031)\end{array}$ & $\begin{array}{c}5.847 \\
(4.263)\end{array}$ & $\begin{array}{c}0.034^{* * * *} \\
(0.004)\end{array}$ \\
\hline White & $\begin{array}{c}8.921 \\
(3.477)\end{array}$ & $\begin{array}{c}798.96 \\
(673.96)\end{array}$ & $\begin{array}{c}0.323 \\
(0.469)\end{array}$ & $\begin{array}{c}0.190 * * * \\
(0.017)\end{array}$ & $\begin{array}{c}63.33 * * * \\
(3.541)\end{array}$ & $\begin{array}{c}0.043 * * * \\
(0.002)\end{array}$ \\
\hline
\end{tabular}

Notes: The first panel compares matched prisoners to the full population of prisoners from 1940. Income and occupation are not reported for prisoners in the census. The second panel compares matched nonprisoners to the 1940 Ipums 1 percent sample. I restrict to men between 18 and 35 years of age. Columns (1)-(3) report means and standard deviations. Coefficients in columns (4)-(6) are from a regression of the outcome of interest on a dummy for being in the matched sample. Regressions include robust standard errors. 
Table B.3: Correlation matrix between heterogeneity variables

\begin{tabular}{l|cccccccc}
\hline & $\begin{array}{c}\text { Black } \\
\text { lit }\end{array}$ & $\begin{array}{c}\text { White } \\
\text { school }\end{array}$ & $\begin{array}{c}\text { Black } \\
\text { share }\end{array}$ & Plantation & $\begin{array}{c}\text { Slave } \\
\text { Share }\end{array}$ & Lynching & Jails & Courts \\
\hline Black lit & 1.00 & & & & & & & \\
White school & -0.024 & 1.00 & & & & & & \\
Black share & -0.153 & -0.040 & 1.00 & & & & & \\
Plantation & -0.123 & 0.001 & 0.430 & 1.00 & & & & \\
Slave share & -0.228 & 0.067 & 0.665 & 0.399 & 1.00 & & & \\
Lynching & -0.194 & -0.012 & 0.232 & 0.226 & 0.253 & 1.00 & & \\
Jails & 0.115 & -0.009 & 0.104 & 0.136 & 0.019 & 0.071 & 1.00 & \\
Courts & 0.117 & 0.015 & 0.095 & 0.174 & -0.020 & -0.003 & 0.279 & 1.00 \\
Thurmond & -0.273 & 0.014 & 0.361 & 0.390 & 0.360 & 0.361 & -0.016 & 0.118 \\
\hline
\end{tabular}

Notes: Each variable is equal to one if that variable is "high". The first five variables are split at the sample median of that characteristic. Lynching is equal to one if the county had a lynching between 1880 and 1920. Jails and courts expenditures are "high" above the sample median. Finally, the Thurmond dummy here is equal to one if Thurmond received more than 40 percent of the vote in the county in the 1948 Presidential election. 


\section{Appendix C: Validation of results with unmatched 1940 Census data}

In this section, I show results using the full count 1940 IPUMS census data. Because prisoners are rarely imprisoned in their county of origin (particularly if they are sent to state or federal prison), I cannot assign exposure based on the 1940 county of residence. Instead, I use the question about location of residence 5 years ago in 1935 to assign exposure based on the SEA of residence in 1935; unfortunately, county of residence in 1935 is not available in the full count data even though it was asked in the census. I look at my full range of ages 18-35.

The main drawback of this design is that by 1935, a large fraction of black men (22\%) are found outside their state of birth. The same is true looking at 18-25 year olds in 1940-20\% have already left their state of birth. If migration is most common in the late teens and early twenties, assigning exposure based on the location in 1935 will give an incorrect measure of exposure to men who migrated. Another drawback is that by 1940, most of the individuals in the sample will have attended school after the Rosenwald schools were built; this reduces the variation in exposure in the data and means that I could have trouble picking up an effect if I include SEA fixed effects. Despite these major drawbacks, I show that my main regression results are similar for this sample. The coefficient on black times exposure is 0.048 which is almost identical to the result in my full 1940 matched sample. This suggests that my main results are not susceptible to significant measurement error. In the full sample, a year of exposure also increases education by 0.216 years which is consistent with the numbers found by Aaronson and Mazumder (2012). 
Table C.1: Results with Unmatched 1940 Census

\begin{tabular}{l|cc}
\hline & $=1$ if in Prison & Years of Education \\
\hline Black*Exposure & $-0.048^{* * *}$ & $0.216^{* * *}$ \\
& $(0.008)$ & $(0.003)$ \\
Exposure & $-0.016^{* * *}$ & $-0.027^{* * *}$ \\
& $(0.006)$ & $(0.002)$ \\
Mean Exposure & 1.016 & 1.015 \\
Sample Mean, black & 1.364 & 1.348 \\
Exposure Measure & "Likely Seats” & "Likely Seats” \\
$\mathrm{N}$ & $4,987,281$ & $4,854,462$ \\
\hline
\end{tabular}

Notes: In the first column, outcome $=100$ if in prison in the adult year. The binary outcome variable is multiplied by 100 so that the coefficients are expressed as percentages instead of proportions. Mean black incarceration rates are given in the row labeled "Sample Mean, black". Regressions include age, black*age, and SEA fixed effects, where SEA is the SEA in 1935. I restrict to ages 18-35. Standard errors are clustered by SEA of residence in 1935. Regressions used the "Likely Seats" measure of exposure. ${ }^{* * *} \mathrm{p}<0.01,{ }^{* *} \mathrm{p}<0.05,{ }^{*} \mathrm{p}<0.10$. 


\section{References}

Aaronson, Daniel and Bhashkar Mazumder. (2011) "The Impact of Rosenwald Schools on Black Achievement," Journal of Political Economy, 119(5): 821-888.

Aaronson, Daniel, Bhashkar Mazumder and Fabian Lange. (2014) "Fertility Transitions Along the Extensive and Intensive Margins”. American Economic Review, 104(11): 3701-24.

Anderson, D. Mark. (2014) "In School and Out of Trouble? The Minimum Dropout Age and Juvenile Crime”. Review of Economics and Statistics. 96(2): 318-331.

Angrist, Joshua D. and Alan B. Krueger. (1992) “The Effect of Age at School Entry on Educational Attainment: An Application of Instrumental Variables with Moments from Two Samples,” Journal of the American Statistical Association 87 (418): 328-336.

Abramitzky, Ran, Leah Boustan, and Katherine Eriksson. (2012) "Europe’s Tired, Poor, Huddled Masses: Self-Selection and Economic Outcomes in the Age of Mass Migration”. American Economic Review. 102(5): 1832-1956.

Atack, Jeremy, Fred Bateman, and Mary Eschelbach Gregson. (1992) “'Matchmaker, Matchmaker, Make Me a Match’: A General Personal Computer-Based Matching Program for Historical Research.” Historical Methods 25(2): 53-65.

Cahalan, Margaret Werner. (1986) "Historical Corrections Statistics in the United States, 18501984.” Rockville, MD: U.S. Department of Justice, Bureau of Justice Statistics. http://www.ncjrs.gov/pdffiles1/pr/102529.pdf.

Carruthers, Celeste and Marianne Wanamaker. (2013). “Closing the gap? The effect of private philanthropy on the provision of African-American schooling in the U.S. south” Journal of Public Economics, 101: 53-67.

Chay, Kenneth and Kaivan Munshi. (2011). "Slavery’s Legacy: Black Mobilization in the Postbellum South” Manuscript, Brown University.

Clark, Damon and Heather Royer. (2010) “The Effect of Education on Adult Health and Mortality: Evidence from Britain”, Working Paper.

Clubb, Jerome M., William H. Flanigan, and Nancy H. Zingale. Electoral Data for Counties in the United States: Presidential and Congressional Races, 1840-1972. ICPSR08611-v1. Ann Arbor, MI: Inter-university Consortium for Political and Social Research(distributor), 2006-11-13. http://doi.org/10.3886/ICPSR08611.v1. 
Collins, William J. and Robert A. Margo. (2006) "Historical Perspectives on Racial Differences in Schooling in the United States," Handbook of the Economics of Education.

Collins, William J., and Marianne H. Wanamaker. (2014). "Selection and Economic Gains in the Great Migration of African Americans: New Evidence from Linked Census Data." American Economic Journal: Applied Economics, 6(1): 220-52.

Cunha, Flavio, Heckman, James J., Lochner, Lance J. and Masterov, Dimitriy V. (2006). " Interpreting the Evidence on Life Cycle Skill Formation, , In Handbook of the Economics of Education, edited by E. Hanushek and F. Welch. Amsterdam: North Holland, Chapter 12: 697-812.

Currie, Janet and Enrico Moretti. (2003) "Mother's Education and the Intergenerational Transmission of Human Capital: Evidence from College Openings," Quarterly Journal of Economics, 118(4): 1495-1532.

de Walque, Damien. (2007) "Does Education Affect Smoking Behaviors?: Evidence Using the Vietnam Draft as an Instrument for College Education,” Journal of Health Economics, 26: 877-95.

Dee, Thomas S. (2004) “Are there Civic Returns to Education?” Journal of Public Economics, 88(9-10): 1697-1720.

Deming, Daniel. (2011) “Better Schools, Less Crime”. Quarterly Journal of Economics, 126(4): 2063-2115.

Donohue, John, James J. Heckman and Petra E. Todd. (2002) "The Schooling of Southern Blacks: The Roles of Legal Activism and Private Philanthropy, 1910-1960," The Quarterly Journal of Economics, 117(1): 225-268.

Espy, M. Watt, and John Ortiz Smykla. EXECUTIONS IN THE UNITED STATES, 1608-2002: THE ESPY FILE. 4th ICPSR ed. Compiled by M. Watt Espy and John Ortiz Smykla, University of Alabama. Ann Arbor, MI: Inter-university Consortium for Political and Social Research(producer and distributor), 2004. http://doi.org/10.3886/ICPSR08451.v4

Ferrie, Joseph. (1996) “A New Sample of Males Linked from the Public Use Micro Sample of the 1850 U.S. Federal Census of Population to the 1860 U.S. Federal Census Manuscript Schedules.” Historical Methods 29: 141-56. 
Glied, Sherry and Adriana Lleras-Muney. (2008) "Health Inequality, Education and Medical Innovation” Demography, 45(3): 741-761.

Greene, William. (2004). "The behavior of the maximum-likelihood estimator of limited dependent variable models in the presence of fixed effects”. Econometric Journal 7: 98119.

Haines, Michael R., and Inter-university Consortium for Political and Social Research. Historical, Demographic, Economic, and Social Data: The United States, 1790-2002. ICPSR02896-v3. Ann Arbor, MI: Inter-university Consortium for Political and Social Research(distributor), 2010-05-21. http://doi.org/10.3886/ICPSR02896.v3

Heckman, James, Thomas M. Lyons and Petra E. Todd. (2000) "Understanding Black-White Wage Differentials, 1960-1990", The American Economic Review: Papers and Proceedings of the One Hundred Twelfth Annual Meeting of the American Economic Association. 90(2): 344-349.

Hjalmarsson, Randi, Helena Holmlund and Matthew J. Lindquist. (2011) "The Effect of Education on Criminal Convictions and Incarceration: Causal Evidence from Micro-data," CEPR Discussion Paper 8646, November.

Hollandsworth, James. (2008) Portrait of a Scientific Racist: Alfred Holt Stone of Mississippi. LSU press: New Orleans, Louisiana.

Japelli, T, J Pischke, and N Souleles. (1998) "Testing for Liquidity Constraints in Euler Equations with Complementary Data Sources," The Review of Economics and Statistics. 80: 251-262.

Klein, Alex. (2009) "Personal Income of U.S. States. Estimates for the period 1880-1910". Warwick Economic Research Papers, no. 916, Department of Economics, University of Warwick.

Kreisman, Daniel. (2015). "The Next Needed Thing: The impact of the Jeanes Fund on Black schooling in the South, 1900-1930.” Forthcoming, Journal of Human Resources.

Langan, Patrick. (1991) Race of Prisoners Admitted to State and Federal Institutions, 1926-86. Department of Justice: Washington, D.C.

Levitt, Steven D. (2004) “Understanding why crime fell in the 1990's: Four factors that explain the decline and six that do not”. Journal of Economic Perspectives. 18(1): 163-190. 
Lleras-Muney, Adriana. (2002) "Were Compulsory Attendance and Child Labor Laws Effective: An Analysis from 1915 to 1939” Journal of Law and Economics, 45(2) 401-435.

Lleras-Muney, Adriana. (2005) "The Relationship Between Education and Adult Mortality in the United States,” Review of Economic Studies, 72(1): 189-221.

Lochner, Lance and Enrico Moretti, (2004) "The Effect of Education on Crime: Evidence from Prison Inmates, Arrests, and Self-Reports," American Economic Review, 94(1): 155-189.

Machin, Stephen, Olivier Marie, and Sunčica Vujić. (2011) "The Crime Reducing Effect of Education,” Economic Journal 121: 463-484.

Manacorda, M. and E. Moretti. (2006) "Why Do Most Italian Young Men Live With Their Parents? Intergenerational Transfers and Household Structure", Journal of the European Economic Association, 4 (4): 800-829.

Margo, Robert. (1990) Race and Schooling in the South, 1880-1950: An Economic History, NBER Books, National Bureau of Economic Research, Inc.

McCrary, Justin and Heather Royer. (2009) "The Effect of Female Education on Fertility and Infant Health: Evidence from School Entry Policies Using Exact Date of Birth,” NBER Working Paper No. 12329.

Meghir, Costas and Mårten Palme. (2005) "Educational Reform, Ability, and Family Background,” American Economic Review 95(1): 414-424.

Meghir, Costas, Mårten Palme, and Marieke Schnabel. (2011) "The Effect of Education Policy on Crime: An Intergenerational Perspective,” Research Papers in Economic No. 2011: 23, Department of Economics, Stockholm University.

Moehling, Caroline, and Anne Morrison Piehl. (2014) "Immigrant Assimilation into US prisons, 1900-1930” Journal of Population Economics 27(1): 173-200.

Muller, Christopher. (2012) "Northward Migration and the Rise of Racial Disparity in American Incarceration, 1880-1950” American Journal of Sociology. 118(2): 281-326.

Naidu, Suresh. (2010) "Recruitment Restrictions and Labor Markets: Evidence from the PostBellum U.S. South” Journal of Labor Economics. April. 
North Carolina Department of Public Instruction. (1937) Educational Directory of North Carolina. Raleigh, NC.

North Carolina Department of Public Instruction. (1942) Educational Directory of North Carolina. Raleigh, NC.

Oshinsky, David M. (1996). "Worse Than Slavery": Parchman Farm and the Ordeal of Jim Crow Justice. New York: The Free Press.

Petersilia, Joan and Kevin R. Reitz. (2012) Oxford Handbook of Sentencing and Corrections. Oxford University Press: 6-7.

Project HAL Data Collection Project, http://people.uncw.edu/hinese/HAL/HAL\%20Web\%20Page.htm. Last accessed December 20, 2014.

Sampson, Robert J. and William Julius Wilson. (2005) "Toward a Theory of Race, Crime, and Urban Inequality” in Race, Crime, and Justice: A Reader. Ed: Shaun Gabbidon: 177-189.

Ruggles, Steven J., Trent Alexander, Katie Genadek, Ronald Goeken, Matthew B. Schroeder, and Matthew Sobek. (2010) Integrated Public Use Microdata Series: Version 5.0 (Machine-readable database). Minneapolis: University of Minnesota.

Sanders, Wiley Britton. (1933) Negro Child Welfare in North Carolina: A Rosenwald Study. University of North Carolina Press: Chapel Hill, North Carolina.

Sanders, Wiley Britton. (1948) Juvenile Courts in North Carolina. University of North Carolina Press: Chapel Hill, North Carolina.

Sanders, Wiley Britton. (1968) Negro Child Welfare in North Carolina. University of North Carolina Press: Chapel Hill, North Carolina.

Schmidt, John, Kris Warner, and Sarika Gupta. (2010) "The High Budgetary Cost of Incarceration.” The Center for Economic and Policy Research, Washington DC.

Sechrist, Robert P. Prohibition Movement in the United States, 1801-1920. ICPSR08343-v2. Ann Arbor, MI: Inter-university Consortium for Political and Social Research(distributor), 2012-10-26. http://doi.org/10.3886/ICPSR08343.v2 
Sellin, Thorsten. (1928) "The Negro Criminal: A statistical note”. Annals of the American Academy of Political and Social Science. November: 52-64.

Siedler, Thomas. (2007) "Schooling and Citizenship: Evidence from Compulsory Schooling Reforms,” Discussion Papers of DIW Berlin 665, DIW Berlin, German Institute for Economic Research.

Siedler, Thomas. (2010) "Schooling and Citizenship in a Young Democracy: Evidence from Postwar Germany,” Scandinavian Journal of Economics, 112(2): 315-338.

Silles, Mary A. (2009) "The Causal Effect of Education on Health: Evidence from the United Kingdom,” Economics of Education Review, 28: 122-128

Smith, James and Finis Welch. (1989). “Black Economic Progress after Myrdal” Journal of Economic Literature 27(2): 519-64.

Solon, Gary and Atsushi Inoue. (2010) "Two-Sample Instrumental Variables Estimators,” Review of Economics and Statistics 92, August: 557-561.

Stephenson, Gilbert. (1917) “Education and Crime Among Negroes”. South Atlantic Quarterly, 16: 16-20.

Stratton, John Roach. (1900) "Will Education Solve the Race Problem?” The North American Review. 170(523): 785-801.

U.S. Department of Commerce and Labor, Bureau of the Census. 1906. Wealth, Debt and Taxation. Washington D.C.

Western, Bruce, Jeffrey R. Kling, and David Weiman. (2001) “The Labor Market Consequences of Incarceration”. Crime and Delinquency. 47(3): 410-427.

Washington, Booker T. (1900) "Will Education Solve the Race Problem: A Reply”. The North American Review. 170(525): 221-232. 


\section{Figures}

\section{Figure 1: Federal and State Admission Rates by Race and Region, 1926-1986}

A: Whole US

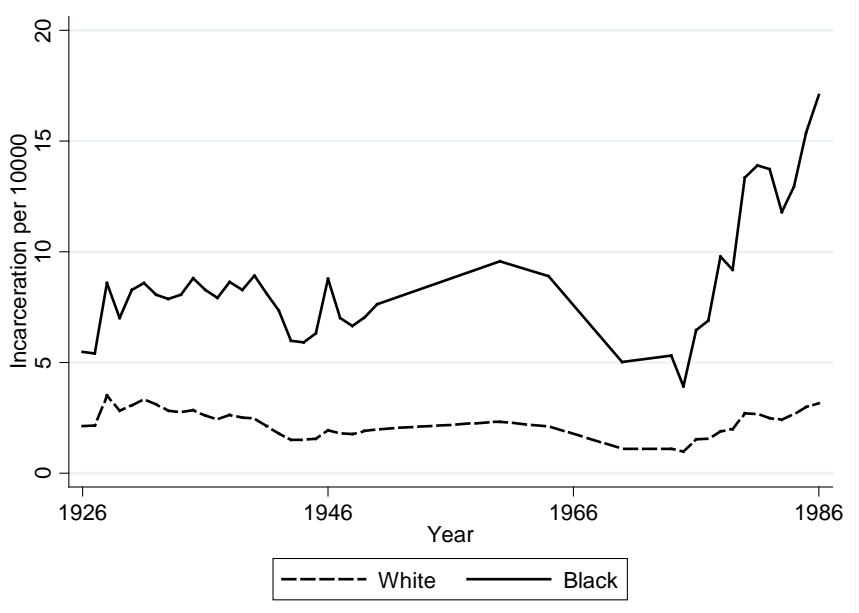

\section{B: Southern States}

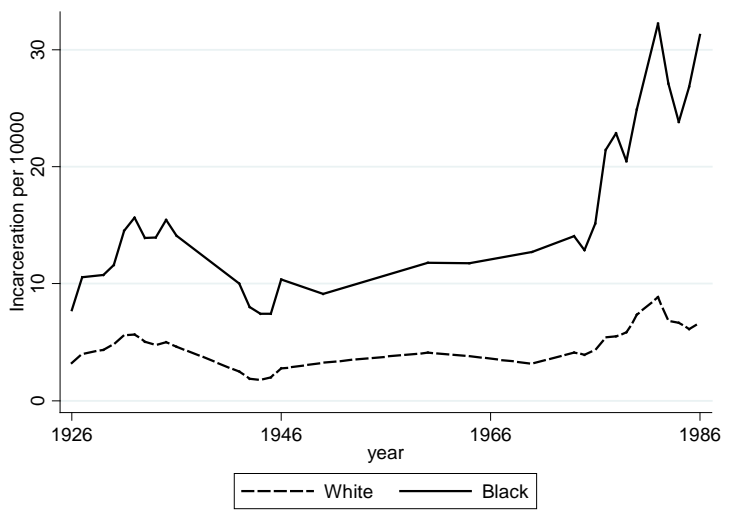

C. Northern States

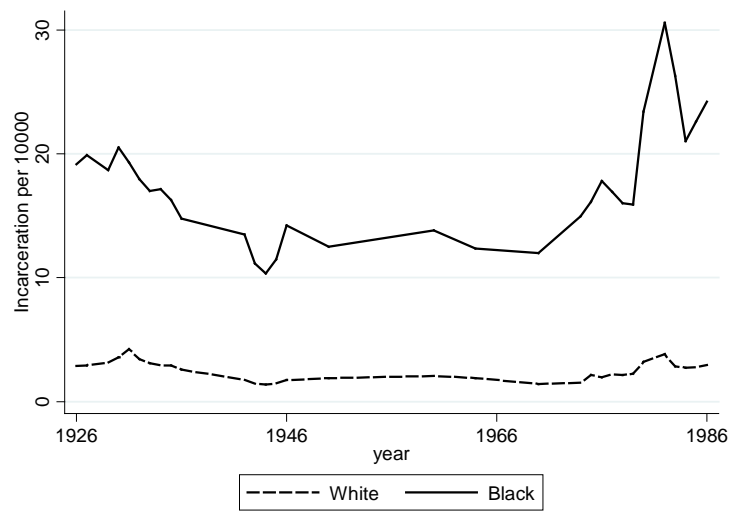

Source: Langan, 1991

Notes: Values are interpolated for years in which data was not available. Numbers are calculated based on the subset of states for which data is available for the whole period: Northern: ; Southern: 
$\underline{\text { Tables }}$

Table 1: Summary Statistics

\begin{tabular}{|c|c|c|}
\hline \multirow{2}{*}{$\begin{array}{l}\text { Sample Size } \\
\end{array}$} & \multirow{2}{*}{ Prisoner } & \multirow{2}{*}{ Non-Prisoner } \\
\hline & & \\
\hline Black & 7,544 & 50,093 \\
\hline White & 10,292 & 311,468 \\
\hline In Prison (weighted percentage) & & \\
\hline Black & 1.408 & \\
\hline 1940 & 1.711 & \\
\hline 1930 & 1.451 & \\
\hline 1920 & 0.994 & \\
\hline White & 0.343 & \\
\hline 1940 & 0.487 & \\
\hline 1930 & 0.416 & \\
\hline 1920 & 0.128 & \\
\hline Age & $\begin{array}{c}26.20 \\
(4.657)\end{array}$ & $\begin{array}{c}26.48 \\
(5.096)\end{array}$ \\
\hline Average Exposure (Likely Seats) & $\begin{array}{c}0.437 \\
(1.031)\end{array}$ & $\begin{array}{c}0.342 \\
(0.906)\end{array}$ \\
\hline Average Exposure (School in County) & $\begin{array}{c}1.834 \\
(2.379)\end{array}$ & $\begin{array}{c}1.356 \\
(2.513)\end{array}$ \\
\hline $\begin{array}{l}\text { Percentage living outside of the South } \\
\text { Black }\end{array}$ & 21.19 & 14.34 \\
\hline 1940 & 0.221 & 0.141 \\
\hline 1930 & 0.275 & 0.105 \\
\hline 1920 & 0.211 & 0.031 \\
\hline White & & \\
\hline 1940 & 0.218 & 0.091 \\
\hline 1930 & 0.236 & 0.070 \\
\hline 1920 & 0.311 & 0.043 \\
\hline Education (1940 Only) & & \\
\hline Black & $\begin{array}{c}5.541 \\
(3.421)\end{array}$ & $\begin{array}{c}5.837 \\
(3.298)\end{array}$ \\
\hline White & $\begin{array}{c}7.489 \\
(3.422)\end{array}$ & $\begin{array}{c}8.921 \\
(3.477)\end{array}$ \\
\hline
\end{tabular}

Notes: statistics are weighted by sample weights which are inversely proportional to the match rate in the year-race-prisoner cell. $\mathrm{N}=379,397$. 
Table 2: Reduced Form Results: Whole South

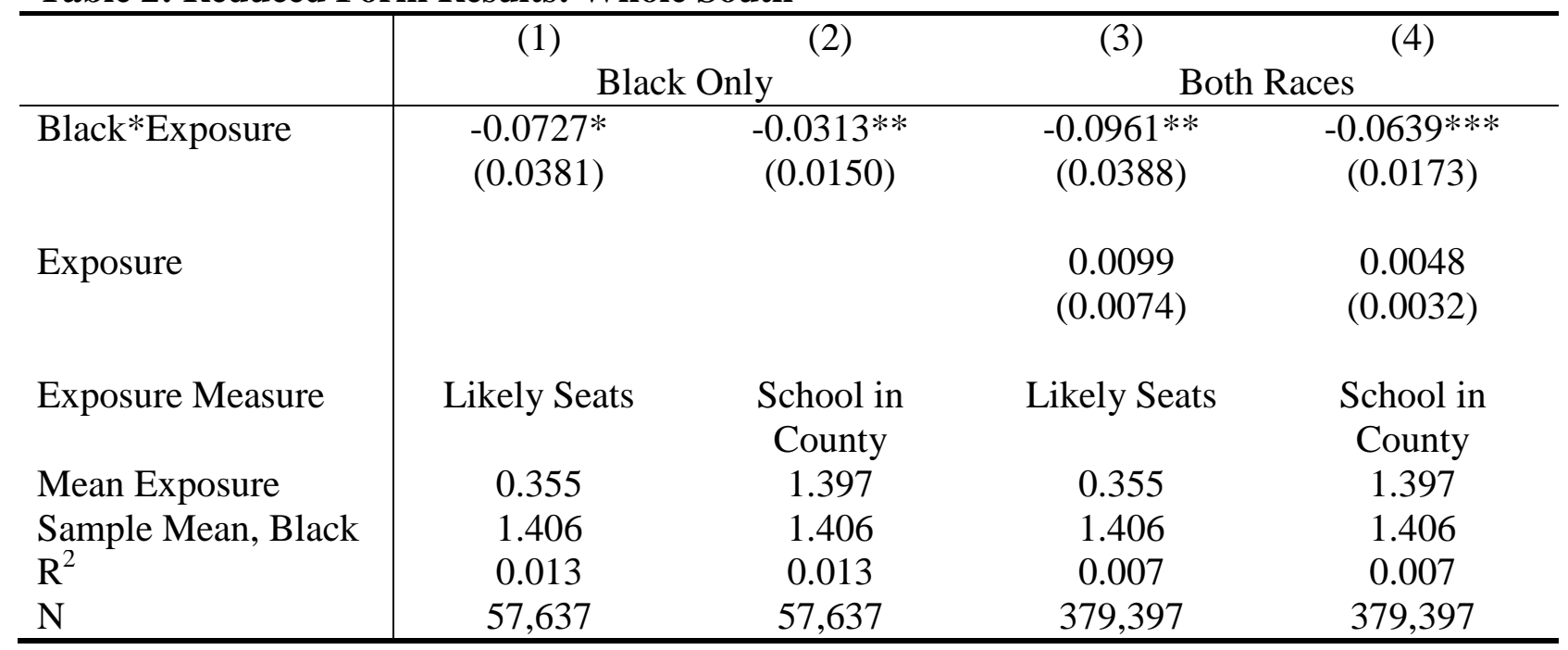

Notes: Outcome $=100$ if in prison in the adult year. The binary outcome variable is multiplied by 100 so that the coefficients are expressed as percentages instead of proportions. Mean black incarceration rates are given in the row labeled "Sample Mean, black". Regressions include age, black*age, year, black*year, state*year, and county fixed effects, where year refers to the childhood census year, and county and state refer to the childhood census county and census state, respectively. I restrict to ages 18-35. Standard errors are clustered by childhood census county. ${ }^{* * *} \mathrm{p}<0.01,{ }^{* *} \mathrm{p}<0.05,{ }^{*} \mathrm{p}<0.10$. 
Table 3: Reduced Form Results, North Carolina

\begin{tabular}{l|ccc}
\hline & $(1)$ & $(2)$ & $(3)$ \\
\hline Black*Exposure & $-0.2143^{*}$ & $-0.1444^{* * *}$ & $-0.1115^{* * *}$ \\
& $(0.1127)$ & $(0.0498)$ & $(0.0100)$ \\
Exposure & 0.0078 & -0.0136 & -0.0073 \\
& $(0.0245)$ & $(0.0193)$ & $(0.0386)$ \\
Mean Exposure & 1.309 & 3.551 & 2.164 \\
Sample Mean, black & 2.052 & 2.052 & 2.052 \\
Exposure Measure & Likely Seats & School in County & Local Radius \\
& & & \\
$\mathrm{N}$ & 33,095 & 33,905 & 33,905 \\
\hline
\end{tabular}

Notes: Outcome $=100$ if in prison in the adult year. The binary outcome variable is multiplied by 100 so that the coefficients are expressed as percentages instead of proportions. Mean black incarceration rates are given in the row labeled "Sample Mean, black". Regressions include age, black*age, year, black*year, state*year, and county fixed effects, where year refers to the childhood census year, and county and state refer to the childhood census county and census state, respectively. I restrict to ages 18-35 and to those living in North Carolina in the childhood census. Standard errors are clustered by childhood census county. Regressions used the "Likely Seats" measure of exposure. ${ }^{* * *} \mathrm{p}<0.01,{ }^{* *} \mathrm{p}<0.05,{ }^{*} \mathrm{p}<0.10$. 
Table 4: Effect of Rosenwald Exposure on Education, Income and Migration, 1940 sample

\begin{tabular}{|c|c|c|c|c|c|c|}
\hline Outcome: & $\begin{array}{c}(1) \\
\text { Prison }\end{array}$ & $\begin{array}{c}(2) \\
\text { Education }\end{array}$ & $\begin{array}{c}(3) \\
\text { Some High } \\
\text { School }\end{array}$ & $\begin{array}{c}(4) \\
\text { Completed } \\
\text { High } \\
\text { School }\end{array}$ & $\begin{array}{c}(3) \\
\text { Ln(Income) }\end{array}$ & $\begin{array}{c}\text { (4) } \\
=1 \text { if } \\
\text { outside of } \\
\text { South in } \\
1940\end{array}$ \\
\hline Black*Exposure & $\begin{array}{l}-0.0466 \\
(0.0450)\end{array}$ & $\begin{array}{c}0.1125^{* * * *} \\
(0.0375)\end{array}$ & $\begin{array}{c}0.0135 * * * \\
(0.0025)\end{array}$ & $\begin{array}{c}0.0063 * * * \\
(0.0019)\end{array}$ & $\begin{array}{c}0.0163 * * \\
(0.0081)\end{array}$ & $\begin{array}{c}-0.0040 * * \\
(0.0015)\end{array}$ \\
\hline Exposure & $\begin{array}{c}0.0025 \\
(0.0222)\end{array}$ & $\begin{array}{l}-0.0006 \\
(0.0010)\end{array}$ & $\begin{array}{l}-0.0028 \\
(0.0012)\end{array}$ & $\begin{array}{l}-0.0016 \\
(0.0010)\end{array}$ & $\begin{array}{c}0.0047 \\
(0.0041)\end{array}$ & $\begin{array}{c}0.0002 \\
(0.0008)\end{array}$ \\
\hline Mean Exposure & 0.9325 & 0.9325 & 0.9325 & 0.9325 & 0.8342 & 0.9325 \\
\hline $\begin{array}{l}\text { Sample Mean, } \\
\text { black }\end{array}$ & 0.707 & 6.133 & 0.2303 & 0.1056 & 5.734 & 0.1809 \\
\hline $\begin{array}{l}\text { R-Squared } \\
\mathrm{N}\end{array}$ & $\begin{array}{c}0.0060 \\
245,492\end{array}$ & $\begin{array}{c}0.2012 \\
245,492\end{array}$ & $\begin{array}{c}0.1448 \\
245,492\end{array}$ & $\begin{array}{c}0.0908 \\
245,492\end{array}$ & $\begin{array}{c}0.2419 \\
155,217\end{array}$ & $\begin{array}{c}0.0804 \\
253,125\end{array}$ \\
\hline
\end{tabular}

Notes: In column 1, outcome $=100$ if in prison in the adult year. The coefficients are interpreted as percentages rather than proportions. Black means of the outcome variable are given in the row labelled "Sample Mean, black". Regressions include age, black*age, year, black*year, state*year, and county fixed effects, where year refers to the childhood census year, and county and state refer to the childhood census county and census state, respectively. I restrict to ages 1835. Standard errors are clustered by childhood census county. Regressions used the "Likely Seats" measure of exposure. ${ }^{* * *} \mathrm{p}<0.01,{ }^{* *} \mathrm{p}<0.05,{ }^{*} \mathrm{p}<0.10$. 
Table 5: Heterogeneity-differential effects by county economic characteristics
(1)

(7)

(8)

(9)

(10)

\begin{tabular}{|c|c|c|c|c|c|c|c|c|c|c|}
\hline Group: & $\begin{array}{c}\text { High black } \\
\text { lit }\end{array}$ & $\begin{array}{c}\text { Low black } \\
\text { lit }\end{array}$ & $\begin{array}{c}\text { High white } \\
\text { schooling }\end{array}$ & $\begin{array}{l}\text { Low white } \\
\text { schooling }\end{array}$ & $\begin{array}{c}\text { High black } \\
\text { population } \\
\text { share }\end{array}$ & $\begin{array}{c}\text { Low black } \\
\text { population } \\
\text { share }\end{array}$ & $\begin{array}{c}\text { High } \\
\text { plantation }\end{array}$ & $\begin{array}{c}\text { Low } \\
\text { plantation }\end{array}$ & $\begin{array}{c}\text { Higher } \\
\text { than Q4 } \\
\text { slave share }\end{array}$ & $\begin{array}{c}\text { Lower } \\
\text { thanQ4 } \\
\text { slave share }\end{array}$ \\
\hline Black*Exposure & $\begin{array}{c}-0.1689 * * * \\
(0.041)\end{array}$ & $\begin{array}{l}0.0207 \\
(0.045)\end{array}$ & $\begin{array}{c}-0.1611^{* * *} \\
(0.042)\end{array}$ & $\begin{array}{l}-0.0272 \\
(0.043)\end{array}$ & $\begin{array}{c}-0.0986 * * * \\
(0.033)\end{array}$ & $\begin{array}{c}-0.1189 * \\
(0.070)\end{array}$ & $\begin{array}{c}-0.0784 * * \\
(0.035)\end{array}$ & $\begin{array}{c}-0.1363 * \\
(0.076)\end{array}$ & $\begin{array}{l}-0.0637 \\
(0.070)\end{array}$ & $\begin{array}{c}-0.0818 * * * \\
(0.030)\end{array}$ \\
\hline Exposure & $\begin{array}{l}0.0032 \\
(0.008)\end{array}$ & $\begin{array}{l}0.0058 \\
(0.009)\end{array}$ & $\begin{array}{c}0.0237 * * * \\
(0.008)\end{array}$ & $\begin{array}{c}-0.0061 \\
(0.009)\end{array}$ & $\begin{array}{l}0.0153 \\
(0.010)\end{array}$ & $\begin{array}{l}0.0076 \\
(0.007)\end{array}$ & $\begin{array}{l}0.0092 \\
(0.009)\end{array}$ & $\begin{array}{l}0.0002 \\
(0.009)\end{array}$ & $\begin{array}{l}0.0105 \\
(0.008)\end{array}$ & $\begin{array}{c}-0.0186 * \\
(0.010)\end{array}$ \\
\hline
\end{tabular}

\section{Significant}

Difference?

Mean Incarc.

Rate, Black

Average

$\begin{array}{cccc}1.682 & 1.202 & 1.401 & 1.408 \\ 0.350 & 0.392 & 0.356 & 0.349 \\ 0.008 & 0.006 & 0.006 & 0.007 \\ 189,527 & 149,867 & 196,242 & 175,958\end{array}$

1.271
0.363
0.006
189,577

2.302
0.340
0.008
182,794

1.244
0.329
0.006
191,397

2.169
0.363
0.009
127,405

1.241
0.355
0.008
161,499

2.108

R-squared

Observations

(8) are defined as "High" and "Low" based on the cutoffs used by Aaronson and Mazumder (2012). Original data for columns (1)-(6) is from ICPSR 2896 and from Chay and Munshi (2011) for columns (7)-(10). The row "Significant Difference" tests whether the coefficients are significantly different using Stata's suest command. Regressions include age, black*age, year, black* year, state*year and county fixed effects, where year refers to the childhood census year. Standard errors are clustered at the childhood census county level. *** $\mathrm{p}<0.01,{ }^{* *} \mathrm{p}<0.05,{ }^{*} \mathrm{p}<0.10$. 
Table 6: Heterogeneity—differential effects by criminal justice and racial attitudes

\begin{tabular}{|c|c|c|c|c|c|c|c|c|}
\hline & (1) & (2) & (3) & (4) & (5) & (6) & (7) & (8) \\
\hline Black*Exposure & $\begin{array}{l}-0.0132 \\
(0.039)\end{array}$ & $\begin{array}{c}-0.2281 * * * \\
(0.049)\end{array}$ & $\begin{array}{c}-0.1994 * * * \\
(0.054)\end{array}$ & $\begin{array}{c}-0.1507 * * * \\
(0.055)\end{array}$ & $\begin{array}{c}-0.2083^{* * *} \\
(0.054)\end{array}$ & $\begin{array}{c}-0.1443^{* * *} \\
(0.054)\end{array}$ & $\begin{array}{c}-0.0174 \\
(0.053)\end{array}$ & $\begin{array}{c}-0.1193^{* * * *} \\
(0.052)\end{array}$ \\
\hline Exposure & $\begin{array}{l}-0.0011 \\
(0.009)\end{array}$ & $\begin{array}{c}0.0217 * * * \\
(0.008)\end{array}$ & $\begin{array}{c}-0.0401 * * * \\
(0.015)\end{array}$ & $\begin{array}{c}-0.0319 * * \\
(0.012)\end{array}$ & $\begin{array}{c}-0.0301 * * \\
(0.014)\end{array}$ & $\begin{array}{c}-0.0336 * * * \\
(0.013)\end{array}$ & $\begin{array}{l}-0.0002 \\
(0.015)\end{array}$ & $\begin{array}{l}0.0091 \\
(0.008)\end{array}$ \\
\hline $\begin{array}{l}\text { Significant } \\
\text { Difference? }\end{array}$ & \multicolumn{2}{|c|}{$\mathrm{Y}^{* * *}$} & \multicolumn{2}{|c|}{$\mathrm{Y}^{* *}$} & \multicolumn{2}{|c|}{$\mathrm{Y}^{* * *}$} & \multicolumn{2}{|c|}{$\mathrm{Y}^{* *}$} \\
\hline R-squared & 0.006 & 0.007 & 0.019 & 0.014 & 0.018 & 0.016 & 0.006 & 0.008 \\
\hline Observations & 199,318 & 175,546 & 145,986 & 147,603 & 152,962 & 153,096 & 88,990 & 271,576 \\
\hline
\end{tabular}

Notes: Regressions split the sample by the relevant characteristic of the childhood county. Sources for data for columns (3)-(10) is described in the text. Had Lynching is equal to one if the county had a lynching in the 40 years before 1920. County expenditure patterns are taken from the US Department of Commerce (1906) which includes county level revenues and expenditures from the 1902 Census of Government. High and Low are defined by the sample median. High Thurmond vote share is defined as more than 40 percent of the county having voted for Strom Thurmond in the 1948 presidential election. The row "Significant Difference" tests whether the two relevant coefficients are significantly different using Stata's suest command. Regressions include age, black*age, year, black*year, state*year and county fixed effects, where year refers to the childhood census year. Standard errors are clustered at the childhood census county level. ${ }^{* * *} \mathrm{p}<0.01,{ }^{* *} \mathrm{p}<0.05,{ }^{*} \mathrm{p}<0.10$. 
Table 7: Effect of Rosenwald Schools on County/Race Admissions to North Carolina State Prison

Dependent variable= Number of prisoners from county in each year, by race

\begin{tabular}{|c|c|c|}
\hline Outcome: & $\begin{array}{c}(1) \\
\text { Level }\end{array}$ & $\begin{array}{c}(2) \\
\text { Log }\end{array}$ \\
\hline Black*Exposure & $\begin{array}{c}-5.305^{* * *} \\
(1.094)\end{array}$ & $\begin{array}{c}-0.193^{* * *} \\
(0.054)\end{array}$ \\
\hline Exposure & $\begin{array}{c}2.349 \\
(1.937)\end{array}$ & $\begin{array}{c}0.052 \\
(0.041)\end{array}$ \\
\hline Black & $\begin{array}{c}40.71^{* * *} \\
(8.711)\end{array}$ & $\begin{array}{c}0.543^{* * *} \\
(0.156)\end{array}$ \\
\hline $\begin{array}{l}\text { Exposure } \\
\text { Years } \\
\text { Sample Mean } \\
\text { Average exp. } \\
\text { R-squared } \\
\text { N }\end{array}$ & $\begin{array}{c}\text { Likely Seats } \\
1935-50 \\
73.26 \\
2.335 \\
0.7350 \\
3,200\end{array}$ & $\begin{array}{c}\text { Likely Seats } \\
1935-50 \\
3.420 \\
2.310 \\
0.7876 \\
3,064\end{array}$ \\
\hline
\end{tabular}

Notes: Regressions include county and race-specific year fixed effects. Standard errors are clustered at the county level. Controls are included in all regressions: total black and white male populations, total population, share urban in the county, and share black in the county. $* * * \mathrm{p}<0.01,{ }^{* *} \mathrm{p}<0.05,{ }^{*} \mathrm{p}<0.10$. 
Table 8: Effect of Rosenwald Exposure on North Carolina Attorney General Reports of County Court Cases

Dependent variable $=$ Number of court cases in county by year, by race

\begin{tabular}{l|cc}
\hline & $(1)$ & $(2)$ \\
& Level & Log \\
\hline Black*Exposure & $-17.60^{* * *}$ & $-0.297^{* *}$ \\
& $(6.791)$ & $(0.135)$ \\
& & \\
Exposure & 7.803 & $0.098^{*}$ \\
& $(4.977)$ & $(0.053)$ \\
& & \\
& $-23.43^{* * *}$ & $-0.345^{* * *}$ \\
& $(6.429)$ & $(0.135)$ \\
Exposure & & \\
Sample Mean & Likely Seats & Likely Seats \\
Average exp. & 69.68 & 3.644 \\
R-squared & 0.496 & 0.495 \\
$\mathrm{~N}$ & 0.6986 & 0.5987 \\
\hline
\end{tabular}

Notes: Regressions include county and race-specific year fixed effects. Standard errors are clustered at the county level. Controls are included in all regressions: total black and white male populations, total population, share urban in the county, and share black in the county. ${ }^{* * *} \mathrm{p}<0.01,{ }^{* *} \mathrm{p}<0.05,{ }^{*} \mathrm{p}<0.10$. 
Table 9: Results from North Carolina Juvenile Crime Data

Dependent variable $=$ Number of Juvenile Court Cases per race in a five year period.

\begin{tabular}{l|cc}
\hline & $(1)$ & $(2)$ \\
& Level & Log \\
\hline Black*Exposure & $-9.484^{* * *}$ & $-0.344^{* * *}$ \\
& $(2.564)$ & $(0.046)$ \\
Exposure & 1.802 & -0.026 \\
& $(5.62)$ & $(0.101)$ \\
Black & & \\
& $17.21^{*}$ & $0.465^{* * *}$ \\
Exposure & $(9.272)$ & $(0.166)$ \\
Sample Mean & & \\
Avg. Exposure & Likely Seats & Likely Seats \\
R-squared & 50.54 & 2.833 \\
$\mathrm{~N}$ & 0.425 & 0.421 \\
\hline Notes: All regressions & 0.8529 & 0.7349 \\
\hline
\end{tabular}

Notes: All regressions include county and race-specific year fixed effects. Controls include total black male population, total white male population, total county population, county share urban, and county share black in the respective year. ${ }^{* * *} \mathrm{p}<0.01,{ }^{* *} \mathrm{p}<0.05,{ }^{*} \mathrm{p}<0.10$. 
Table 10: Robustness, Full Sample

Dependent Variable $=100$ if individual is incarcerated

\begin{tabular}{l|c}
\hline Restriction & Coefficient on Black*Exposure \\
\hline 1. None & $-0.0961^{* *}$ \\
2. Ages 18-30 & $(0.039)$ \\
& $-0.0708^{* *}$ \\
3. Restrict to non-Tuskegee Counties & $(0.038)$ \\
& $-0.1308^{* * *}$ \\
4. Add black* county FE & $(0.039)$ \\
& $-0.0794^{* *}$ \\
5. Add year*county FE & $(0.039)$ \\
& $-0.1129 * *$ \\
6. Add state*cohort trends & $(0.044)$ \\
& $-0.0960^{* * *}$ \\
7. Add county*cohort trends & $(0.039)$ \\
\end{tabular}

Notes: $\mathrm{N}=379,397$. Regressions include age, black*age, state*year, year, black*year, and and county fixed effects, where year refers to the childhood census year. In rows 6 and 7, county and state are measured in the childhood census year. Restrictions are explained in detail in the text. Exposure is measured using the "Likely Seats" measure. Standard errors are clustered at the childhood census county level. ${ }^{* * *} \mathrm{p}<0.01,{ }^{* *} \mathrm{p}<0.05,{ }^{*} \mathrm{p}<0.10$. 